\title{
Santa María de Huerta, panteón de la nobleza castellana $^{1}$
}

\author{
María Teresa López de Guereño Sanz \\ Universidad Autónoma de Madrid
}

RESUMEN. El monasterio de Santa María de Huerta se convirtió, durante la Edad Media, en la morada eterna de miembros de las más nobles familias castellanas. Desde el último tercio del siglo XII, la comunidad hortense recibió por parte de ellos fuertes ingresos para ejecutar sus obras, a condición de que se les concediese sepultura entre sus muros. Los monjes, a su vez, y en agradecimiento a las donaciones de sus benefactores, se obligaban a rezar por sus almas y custodiar sus sepulcros. En la iglesia, Martín de Finojosa, Rodrigo Jiménez de Rada y los Condes de Medinaceli; en el claustro, anhelando un enterramiento de prestigio, las familias de los Molina, Bera, Montuenga, etc., contribuyeron con sus donaciones y sepulcros a hacer realidad el esplendor de la fábrica monástica y, al mismo tiempo, al alejamiento del ideal monástico de pobreza y austeridad promulgado por los fundadores de la orden..

Palabras clave: Arquitectura Monástica. Claustro. Panteón. Sepulcros. Arcosolios.

ABSTRACT. Santa María de Huerta's monastery became, during Middle Age, the eternal dwelling of members from the noblest Castilian families. From the last third of XII Century, Huerta's community received from them important incomes to execute their works; with the only condition that grave was granted to them within their walls. The monks, on their side, and in gratitude for the donations from their benefactors, obliged themselves to pray for their souls and to custody their sepulchres. In the church, Martín de Finojosa, Rodrigo Jiménez de Rada and the Counts of Medinaceli; in the cluster, yearning for a prestigious burial, the families Molina, Bera, Montuenga, etc., contributed with their donations and sepulchres to make the splendour of the monastic factory a reality and, at the same time, to grow the distance from the monastic ideal of poverty and austerity promulgated by the founders of the order.

Key words: Monastic Architecture. Cloister. Pantheon. Sepulchres. Wall-tomb.

La idea de la muerte obsesionó al hombre medieval durante toda su existencia hasta tal punto que se tradujo en un constante lamento por la caducidad de la vida y gozo por la salvación del alma ${ }^{2}$. Así,

\section{-}

${ }^{1}$ El siguiente estudio pertenece a la ponencia presentada al Seminario ¿Dejar a los muertos enterrar a sus muertos? El difunto entre el aquí y el más allá en España y Francia (ss. XI-XV), organizado por la Casa de Velázquez y el Departamento de Historia y Teoría del Arte de la Universidad Autónoma de Madrid (9-10 de diciembre de 1999).

2 PH. ARIÈS, El hombre ante la muerte, Madrid, 1984, pp. 34-40; Id., Historia de la muerte en Occidente: desde la Edad Media hasta nuestros días, Barcelona, 2000. el concepto de la muerte como tránsito a la

Recientemente se han publicado obras de conjunto sobre este tema, de las que destaco: La idea y el sentimiento de la muerte en la historia y en el arte de la Edad Media, Santiago de Compostela Vol. I , 1988 y Vol. II, 1992; J. AURELL i CARDONA y J. PAVÓN (Coords.), Ante la muerte: actitudes, espacios y formas en la España medieval, Pamplona, 2002; Edad Media: revista de historia, no 6, 2003-2004, dedicado a "La muerte y el más allá"; Semata: Ciencias sociais $e$ humanidades, "; no 17, 2006, dedicado a "Muerte y ritual funerario en la historia de Galicia"; para el caso aragonés el estudio de $M^{a}$ del C. GARCÍA HERRERO y Ma I. FALCÓN PÉREZ, "En torno a la muerte a finales de la Edad Media aragonesa", En la España medieval, no 29, 2006, pp. 153186. 
otra vida se fue reafirmando en estos siglos hasta llegar al XV, momento en que lo meramente religioso se fundirá con aspectos como la fama, el poder, la inmortalidad en el recuerdo etc... Esta actitud incidirá en facetas de la vida cultural como la literatura y las artes, que posibilitarán su reconocimiento en esta vida y la convicción de no ser olvidados ${ }^{3}$.

Así es como debemos entender el cada vez más importante papel que se reservó al lugar elegido para sepultura y a esta misma por contener un reconocimiento de la condición social del difunto y su propio ensalzamiento. Pero no debemos olvidar que, quizás, lo más importante era permanecer en un lugar sagrado hasta que llegara el momento de ser juzgado.

La documentación medieval hace referencia a la idea de entregar el alma a Dios y el cuerpo a la tierra de donde fue tomado; para él se busca el mejor sepulcro posible y, si la fortuna lo permite, el monasterio propio. Este deseo no estaba exento de dificultades porque una fundación, primero, y la construcción del mismo, después, eran enormemente costosas así como las necesidades edilicias o la manutención de una comunidad. Sin embargo, ello no fue impedimento para nobles que deseaban adquirir prestigio social y perpetuar su memoria y la de su linaje a través de la fundación de un monasterio, instando a sus descendientes a culminar lo que ellos habían iniciado ${ }^{4}$.

\footnotetext{
${ }^{3}$ A. Arranz Guzmán, "La reflexión sobre la muerte en el medievo hispánico: ¿Continuidad o ruptura?", En la España Medieval, Madrid, 1986, Tomo V, pp. 109-124, especialmente p. 114; Ma C. Porras Gil, “El concepto de la muerte a finales de la Edad Media", Boletín de la Institución Fernán González, 1993, nํ206, pp. 9-17.

${ }^{4}$ Es el caso de Gómez Manrique en el monasterio de Fresdelval (Burgos) (J. YARZA, “La capilla funeraria hispana en torno a 1400", La idea y el sentimiento de la muerte en la historia y en el arte de la Edad Media (I), Santiago de Compostela, 1988, pp. 67-91).
}

A lo largo del siglo XII los fieles empiezan a manifestar el deseo de enterrarse en el interior de los templos, lo que hasta entonces les había sido negado. Tal pretensión se conseguirá en esta centuria de forma esporádica, generalizándose en la siguiente, aunque con ciertas restricciones. Evidentemente, todos deseaban obtener un lugar lo más cercano posible al presbiterio, pero este espacio era un lugar reservado únicamente a personajes de elevada condición social o religiosa ${ }^{5}$.

Fue la fama de los monjes blancos, basada en la pureza de su ideal monástico con la estricta observancia de la Regla Benedictina, lo que atrajo a esta sociedad. Sin embargo, la orden del Cister, desde su fundación, prohibió expresamente que persona ajena al monasterio recibiera sepultura en el cementerio de la comunidad y, mucho menos, en el claustro o en la iglesia, como se recoge en el Exordium Parvum ${ }^{6}$. Pocos años más tarde, a partir de lo dispuesto en el

-

${ }^{5}$ I. BANGO Torviso, "El espacio para enterramientos privilegiados en la arquitectura medieval española", Anuario del Departamento de Historia y Teoría del Arte (U.A.M.), Vol. IV, 1992, pp. 93-132.

${ }^{6}$ Los estatutos de 1134 prescriben, entre otras cosas, que nadie deberá ser admitido para la confesión, la comunión y la sepultura, salvo los huéspedes y los servidores del monasterio. Cada monje podrá pedir para dos de sus amigos o de sus parientes, con sus esposas, el favor de ser enterrados en el cementerio, convenientemente dividido en dos: uno, el de los hermanos y, otro, el de los laicos (M. AUBERT, L'Architecture cistercienne en France, 2 Vols., París, 1947 (2 $2^{\mathrm{a}}$ Ed.), Vol. I, pp. 329-349, especialmente pp. 329-332 y 347-349). Para todo lo relativo a la legislación cisterciense en materia funeraria, Vid. E. DABROWSKA, "Le rite funéraire progre à l'Ordre de Cîteaux: son développement, sa réception, ses filiations", Unanimité et diversité cisterciennes: filiation, réseaux, relectures $d u$ XIIe au XVII siècle, St.-Étienne, 2000, pp. 223-231 y los diferentes artículos recogidos en Citeaux. Commentarii Cistercienses, 2005, t. 56, fasc. 1-4, número dedicado a las sepulturas, memorias y patrones de los monasterios cistercienses en la Edad Media; también publicado como Sepulturae cistercienses. Sepulture. Mémorie et patronage dans le monastères cisterciens au Moyen Âge, J. HALL y C. KRATZKE (Eds.), 2006. 
Capítulo General de 1152, esta intransigencia se va moderando, permitiéndose que en el interior de los templos reciban sepultura reyes, reinas, arzobispos y obispos, con la condición de que solamente cubra su cuerpo una sencilla lápida, precepto que se mantiene en el Capítulo de 1180. Ni siquiera los abades podían ser enterrados en la iglesia si para ello no había un permiso expreso del abad de Cîteaux ${ }^{7}$ y a los fundadores de la abadía tan sólo se les permitía hacerlo en el interior del recinto ${ }^{8}$.

Esta prohibición no llegó a mantenerse durante mucho tiempo, pues fueron tales las demandas y la insistencia de los fieles por ser aceptados en los cementerios monásticos que el Capítulo General de 1227 cede a estas súplicas a condición de que los sacerdotes de las parroquias den su consentimiento. Incluso, en algunos lugares, desde hacía ya algunos años, se permitía yacer a los benefactores de la abadía en las galerías del claustro, levantando, en ocasiones, mo-

-

${ }^{7}$ Son conocidos los casos de Alberico y Esteban, los dos primeros abades de Cîteaux, considerados santos, a los que se les veta el enterramiento en su iglesia. Por el contrario, sí podían hacerlo en el claustro cerca de la puerta del templo o en la sala capitular, como había dispuesto el Capítulo de 1180. Sin embargo, estas estrictas prescripciones no impidieron que en Francia, a lo largo del siglo XII, varios cenobios contravinieran las normas y fueran sancionados por enterrar, incluso, en el presbiterio de sus iglesias (M. AUBERT, L' Architecture cistercienne, op. cit., Vol. I, p. 329 y SS).

${ }^{8}$ Esta decisión fue tan rigurosa que los duques de Borgoña, fundadores de Cîteaux, fueron enterrados en una capilla cerrada en el pórtico occidental de la iglesia (M. AUBERT, L'Architecture cistercienne, op. cit., Vol. I, p. 330). En este contexto debemos entender las amonestaciones a los abades de Clermont (Mayenne) y de Vaucluisant (Yonne) en 1197-1198 en lo que concierne al enterramiento de los fundadores en la iglesia, cuyo lugar estaba fijado solamente en el recinto del monasterio $\mathrm{y}$, más tarde, en el claustro a nivel del suelo (A. MUSSAT, "Le chevalier et son double: naissance d'une image funéraire (XIIIe siécle)", La figuration des morts dans la chretiente medievale jusqu'a la fin du premier quart du XIV siècle, Premier Cahier de Fontevraud, 1988, pp. 138-154, especialmente p. 143). numentos sobre sus tumbas ${ }^{9}$. Será en la segunda mitad del siglo XIII cuando la negativa para inhumar a los fieles en el interior del recinto desaparezca de los Estatutos de los Capítulos Generales. Cada vez más laicos serán enterrados en el cementerio monástico y los bienhechores más importantes en el claustro e, incluso, en la iglesia, claro indicio de que cierto interés económico les debió llevar a reconsiderar su postura, pues una de las principales fuentes de ingresos iba a provenir de los derechos de entierro. En España y Portugal, también se llevó a cabo un estricto cumplimiento de estas normas, quizás por sus propias tradiciones pues desde el Primer Concilio de Braga, celebrado en el 561, se prohibían los enterramientos dentro de las iglesias, por lo que no tuvieron grandes problemas en acatarlo ${ }^{10}$.

Por lo que se refiere a la realeza, durante el siglo XII algunos monarcas fueron enterrados en los templos. Así por ejemplo,

\section{-}

${ }^{9}$ Esto hizo que el Capítulo General de 1194 obligara a los abades a trasladar las tumbas que impedían la deambulación por el claustro (M. AUBERT, L'Architecture cistercienne, op. cit., Vol. I, p. 330).

10 J. VIVES, Concilios visigóticos e hispanorromanos, Barcelona-Madrid, 1963, Canon XVIII, p. 75. Uno de los ejemplos más claros es el de Domingo Manso que, aún siendo persona de indiscutible autoridad y prestigio, al morir en 1073, es enterrado, no en la iglesia del monasterio de San Sebastián de Silos, sino en el claustro. Sólo tres años después, cuando Domingo ya ha sido beatificado, se le traslada al interior del templo, ante el altar de San Martín, todo ello apoyado en la aquiescencia real y con una amplia justificación, basada en que se trataba ya de un santo (I. G. BANGO TORVISO, "La iglesia antigua de Silos: Del prerrománico al románico pleno", El Románico en Silos. IX Centenario de la Consagración de la iglesia y claustro, Abadía de Silos, 1990, pp. 317-376, especialmente p. 327). Para un estudio del tema desde el punto de vista de la legislación, vid. J. ORLANDIS, "Sobre la elección de sepultura en la España medieval", Anuario del Historia del Derecho Español, 1950, pp. 5-49; para un análisis artistico y documental, vid. de nuevo I. BANGO TORVISO, “El espacio para enterramiento", op. cit.; finalmente, para casos concretos, vid. J. YARZA, "La capilla funeraria hispana", op. cit., pp. 67-91. 
Alfonso VII y su hijo Sancho III en la catedral de Toledo; Fernando II y Alfonso IX en una capilla de la catedral de Santiago de Compostela; Alfonso VIII en la capilla de la Asunción del monasterio de Las Huelgas de Burgos. De esta manera, los poderosos entran en el templo, aunque sólo ocupando espacios muy específicos.

A lo largo del siglo XIII dicha prohibición comienza a remitir y ya en Las Partidas de Alfonso X se da licencia para que los fieles puedan elegir el lugar de su sepultura, convirtiéndose la iglesia en un verdadero espacio privilegiado, frente al cementerio que se destina al común de las gentes ${ }^{11}$. Sin embargo, tanto en Las Partidas ${ }^{12}$ como en el Rationale Divinorum Officiorum de Guillermo Durando ${ }^{13}$ se precisa quiénes son aquellas personas que por su condición pueden se enterradas en el interior de los templos.

Todas estas disposiciones acerca de los preceptos negativos sobre los enterramientos en los monasterios cistercienses fueron contempladas a la hora de construir

-

11 Soterrar deben cada un home en el cementerio de aquella eglesia onde era parroquiano, et do oie las horas quando era vivo et do rescibie los sacramentos. Pero si alguno quisiere recebir sepoltura en otro cementerio, asi como en eglesia catedral, ó en monasterio, ó en quella eglesia do yace su linage, ó en otro cementerio qualquier puédelo facer... (Las Siete Partidas del Rey Don Alfonso el Sabio cotejadas con varios códices antiguos por la Real Academia de la Historia,Tomo I, Partida I, Madrid, 1807, Título XIII, Ley V, Madrid, 1972, pp. 384-385).

12 Enterrar non deben á otro ninguno dentro en la eglesia sinon á estas personas ciertas que son nombradas en esta ley, asi como los reyes et las reynas et sus fijos, et los obispos, et los abades, et los priores, et los maestres et los comendadores que son perlados de las ordenes et de las eglesias conventuales, et los ricos homes, et los otros hombres honrados que ficiesen eglesias de nuevo ó monasterios, et escogesen en ellas sus sepulturas: et todo otro home quier sea clerigo o lego que lo meresciese por santidat de buena vida et de buenas obras... (Id., Partida I, Título XIII, Ley XI, pp. 388-389); J. Yarza LUACES, "Despesas fazen los omnes de muchas guisas en soterrar los muertos", Fragmentos, 1984 , no 2 , pp. 4-19.

13 I. G. BANGO TORVISO, "El espacio para enterramientos", op. cit., pp. 112-114. los edificios; en sus proyectos no se preveía albergar sepulturas y, mucho menos, articular espacios anexos con finalidad funeraria. No obstante, tras el beneplácito de la orden, las fábricas sufrieron sensibles modificaciones que afectaron a todo el recinto monástico llegando incluso, a veces, a convertir el cenobio en un auténtico panteón ${ }^{14}$.

A pesar de que los grandes monasterios medievales tuvieron un espacio cementerial separado de las dependencias de la comunidad, en este sentido hay que destacar que fue el claustro uno de los lugares preferidos para enterramiento, añadiendo a su función litúrgica y de articulación de espacios para la comunidad, la finalidad funeraria ${ }^{15}$. Las pandas se convirtieron en

-

${ }^{14}$ El ejemplo más representativo lo tenemos en Las Huelgas de Burgos, fundación de Alfonso VIII, que había erigido el monasterio como cementerio para él y su familia. Sin embargo, este hecho hace que debamos entender Las Huelgas como una excepción con respecto al resto de los monasterios cistercienses del reino de Castilla y León. Son numerosos los estudios que abordan este aspecto, aunque destaco entre ellos: R. SÁNCHEZ AMEIJEIRAS, "El "çementerio real" de Alfonso VIII en las Huelgas de Burgos", Semata, ciencias Sociais e Humanidades, 1998, Vol. 10, pp. 77-109 y E. CARRERO SANTAMARÍA, “Observaciones sobre la topografía sacra y cementerial de Santa María la Real de Las Huelgas, en Burgos, y su materialización arquitectónica", La clausura femenina en España: Actas del Simposium, Sevi1la, 2004, Vol. 2, pp. 695-716. Para el sepulcro de Alfonso VIII y su esposa vid. O. PÉREZ MONZÓN, "Iconografía y poder real en Castilla: las imágenes de Alfonso VIII", Anuario del Departamento de Historia y Teoría del Arte, Vol. XIV, 2002, pp. 19-41.

${ }^{15}$ Un análisis exhaustivo sobre la arquitectura de los cistercienses en Castilla y León en Monjes y Monasterios. El Cister en el medievo de Castilla y León, Valladolid, 1998. Por lo que se refiere a las diferentes funciones del claustro en época medieval, vid. F. ESPAÑOL BERTRÁN, "La polifuncionalidad de un espacio restringido", Claustros románicos hispanos, J. YARZA LUACES y G. BOTO VARELA (Coords.), León, 2003, pp. 11-29, especialmente pp. 23-25. Sobre los claustros cistercienses en Castilla, vid. J.L. HERnANDO GARRIDO, "Rigor formal y aniconismo. Patios monásticos cistercienses castellanos", Claustros romanicos hispanos, op. cit., pp. 181-193. De forma específica sobre la finalidad funeraria del claustro y su integración en la arquitectura gótica, vid. E. CARRERO SANTAMARÍA, "El claustro 
un lugar de enterramiento de prestigio para personajes estrechamente vinculados a la fundación o a la fábrica del monasterio, de manera que, incluso alguna de las galerías o todo el claustro, acabó siendo bautizado con el nombre de aquellos que habían elegido dicho lugar: "el claustro de los caballeros", como en el caso de Santa María de Huerta. Incluso, en ocasiones esa finalidad funeraria condicionó una determinada articulación muraria retranqueando los arcosolios en los muros perimetrales o, incluso, utilizando los intercolumnios que dan al jardín.

El monasterio de Santa María de Huerta no escapó a esta realidad y, desde sus primeros momentos, se convirtió en la morada eterna de algunos miembros de las más nobles familias castellanas (Figs 1 y 2). Por ello, durante el último tercio del siglo XII, la comunidad hortense recibió de su parte fuertes ingresos para ejecutar sus obras, a condición de obtener sepultura entre sus muros. Los monjes, por su parte, y en agradecimiento a las donaciones de sus benefactores, se obligaban a cuidar los sepulcros y rezar por las almas de aquellos que, con su generosidad, habían contribuido a hacer realidad la construcción del monasterio y a aumentar su patrimonio ${ }^{16}$. Así, una vez más y como ocurre en otros monasterios de la orden, se hace patente el conflicto de, por un lado, aunar la sobriedad exi-

funerario en el medievo o los requisitos de una arquitectura de uso cementerial", Liño, 2006, no 12 , pp. 3143. Finalmente, sobre sepulturas en los monasterios vid. J. MARTÍNEZ DE AGUIRRE, "La memoria de la piedra: sepulturas en espacios monásticos hispanos (siglos XI y XII)", Monasterios Románicos y producción artística, Aguilar de Campóo, 2003, pp. 131-159.

${ }^{16}$ Dedicado de forma monográfica a los monasterios cistercienses en Castilla y León, aunque algo confuso para el caso de Huerta, vid. A. GARCíA FLORES, "Espacios funerarios en los monasterios cistercienses de los reinos de Castilla y de León (Siglos XII al XV)", Citeaux: Commentarii cistercienses, 2005, T. 56, fasc. 1-4, pp. 199-229. gida por los fundadores $\mathrm{y}$, por otro, adaptarse a los gustos y exigencias de una nobleza, que actuaba como protectora del cenobio $^{17}$.

Dichas sepulturas se dispondrán según la estricta jerarquía de los espacios privilegiados destinados a enterramientos (Lám. 1). En Huerta esta circunstancia no significó la creación de una capilla funeraria privada, sin embargo en el templo fueron enterradas las dos figuras más relevantes en el devenir histórico de la abadía: Martín de Finojosa $(+1213)$ y Rodrigo Jiménez de Rada (+1247); el primero, obispo de Sigüenza y abad de Huerta, después, y, el segundo, arzobispo de Toledo. A estos dos hombres de iglesia se les otorga el lugar más destacado posible: el presbiterio. A su vez, los Condes de Medinaceli desearán también ser enterrados junto a ellos, en la capilla mayor. Por el contrario, el claustro acogerá a los nobles castellanos cuyas aportaciones económicas permitieron materializar obras en el monasterio o porque sus victorias frente a los moros les hicieron merecedores de este lugar de enterramiento. Aquí también recibirán sepultura miembros del clero que, de una forma o de otra, habían estado vinculados al abad Finojosa o al arzobispo D. Rodrigo.

\section{ENTERRAMIENTOS EN LA IGLESIA}

Ya hemos visto que el enterramiento en el presbiterio significaba prestigio y se reservaba a personajes de elevada condición social o religiosa ${ }^{18}$, aunque la conquista de este espacio no se produce hasta el siglo $\mathrm{XIII}^{19}$. La dignidad eclesiástica de Jiménez

-

${ }^{17}$ V. GARCía LOBO y Maㅡ E. MARTíN LÓPEZ, “La publicidad en el Cister", Monjes y monasterios, op. cit., 1998, pp. 47-62, especialmente pp. 51-53.

${ }^{18}$ Es preciso recordar aquí cómo, en 1153, San Bernardo fue enterrado en el interior de la iglesia de Clairvaux, ante el altar de Santa María (M. AUBERT, L'Architecture cistercienne, op. cit., Vol. I, p. 348).

${ }^{19}$ En España, los lucillos más antiguos que se 
de Rada hace que consideremos una excepcionalidad la elección de Huerta como morada eterna. Era costumbre entre los eclesiásticos elegir como lugar de enterramiento los templos que regían en el momento del fallecimiento; por ello, hubiera sido más lógico que el arzobispo optara por la catedral de Toledo. Sin embargo, D. Rodrigo, por un documento fechado en París el 24 de abril de 1201, decide enterrarse en Huerta ${ }^{20}$. Evidentemente, este era un gesto de humildad que le ayudaría a alcanzar la salvación eterna, a lo que se añade otro elemento más que debió contribuir a su decisión y es que, en torno a 1200, la cabecera del templo de Huerta está prácticamente ultimada ${ }^{21}$. A todo esto también podemos agregar, el más que posible interés de la comunidad hortense por acoger entre sus muros el cuerpo de un personaje tan insigne como él.

En la actualidad, los sepulcros de Martín de Finojosa y Jiménez de Rada se encuentran haciendo pendant, a ambos lados del altar ${ }^{22}$, aunque éste no fue su em-

abren a los lados del presbiterio son de finales del siglo XIII y, en ningún caso, habían sido previstos en el proyecto original. Por ello, si el fallecimiento de los fundadores de cualquier monasterio se produjo en el siglo XII y hoy sus sepulturas están ubicadas en el presbiterio, esto significa que ha existido una reubicación de sepulcros en fechas posteriores (I. G. BANGO TORVISO, "El ámbito de la muerte", Monjes y Monasterios, op. cit., p. 318).

${ }^{20}$ Notum sit omnibus, tam presentibus quam futuris, quod ego Rodericus Ximenii sepulturam mihi apud Hortam elegi... (A. MANRIQUE, Annales cistercienses, 4 Vols., Lugduni, 1642-1659, Tomo III, p. 375; J.A. GARCíA LUJÁN, Cartulario del Monasterio de Santa María de Huerta, Monasterio de Santa María de Huerta, 1981, pp. 113-114).

${ }^{21}$ M ${ }^{a}$ C. MUÑOZ PÁRRAGA, “Iglesia. Santa María de Huerta (Soria)", Monjes y Monasterios, op. cit., pp. 127-129.

${ }^{22}$ En dos hornacinas, labradas c. 1660 , se alojan sendos sarcófagos: el de D. Rodrigo, en el lado del Evangelio, con el siguiente epitafio:

CONTINET HAEC FOSSA RODERICI CORPUS, ET OSSA,

DE CVIVS MORTE SOLI BENE CONTINGIT HORTAE plazamiento original (Lám. 1, C y D). San Martín estuvo enterrado en el suelo, delante de la grada del Altar Mayor ${ }^{23}$ hasta $1558^{24}$ (Lám. 1, A), momento en el que sería trasladado al lucillo lateral ${ }^{25}$, y D. Rodrigo,

-

PONTIFICVM GEMMA, TOTIVS GLORIA

GENTIS, LAVS DECVS HISPANIAE, VERVS FONS, ARCA SOPHIAE

ET PIVS, ET MITIS CVNCTIS VBERRIMA VITIS

EXTITIT ALVMNIS, CARVIT SVA VITA CALVMNIIS

MATER NAVARRA, NVTRIS CASTELLA, TOLETVM

SEDES, PARISIVS STVDIVM, MORS RHODANVS, HORTA

MAVSOLEVM, COELVM REQUIES, NOMEN RODERICVS

ANNO DOMINI M.CC.XLVII OBIIT ARCHIEPISCOPVS

TOLETANVS IV IDVS IUNII

(A. MANRIQUE, Annales, op. cit., Tomo II, Appendix, p. 19; Tomo IV, p. 16).

El de San Martín, en el de la Epístola, en cuya lápida se leía:

MARTINUM FORTIS RAPUID VERSANIA MORTIS

PONTIFICEM SANCTUM, IUSTUM SOBRIUMQ[Uе] BEATUM

IMPETRARE PIA VIRGO DIGNARE MARIA

UT VITA VINAT MONACHUS TUUS HIC COENOBITA,

CUIUS IN HAC FOSSA CARNES CONDUNTUR [...] OSSA

OCTO BIS OCTOBRIS DISSOLVIT MEMBRA KALENDIS

ANNO AB INCARNATIONE DOMINI MILLESI$M O$

DUECENTESIMO DECIMO

(A. MANRIQUe, Annales, op. cit., Tomo IV, pp. 1617).

${ }^{23}$ C. CORDÓN, Cronología de los Abades de Huerta, varones insignes en dignidad y letras de dicho Monasterio, $y$ vida de los Obispos sus hijos, Ms., Archivo Monasterio de Huerta, 1750, fol. 44.

${ }^{24}$ En este año, el abad Luis de Estrada ... elevó el cuerpo de San Martín que hasta su tiempo estuvo en la tierra y en el suelo de la capilla Mayor y le puso en una caja de madera, no entero, como dice el Sr. Manrique, sino los huesos sin la cabeza, los quales despidieron de si grande fragancia que duro por ocho días en la Yglesia... Mudo a un sepulcro de piedra el cuerpo de Dn Rodrigo.... (C. CORDÓN, Cronología de los Abades, op. cit., fols. 67vtº-68).

${ }^{25}$ En este lugar se depositaron los restos de su madre, Sancha Gómez (+1189), que en principio estuvo sepultada en el cementerio de Huerta (A. MANRIQUE, 
bajo un arco, en el lado del Evangelio ${ }^{26}$ (Lám. 1, B). Sobre la primitiva ubicación de este último, el abad Luis de Estrada nos da la siguiente referencia: ... en la Capilla Real de Nuestra Señora de Huerta, en la pared a la mano derecha, que llamamos del Evangelio, está un sepulcro muy sumptuoso de piedra y muy antiguo, debaxo de un arco y sobre quatro leones o perros de piedra muy fieros, en el qual está enterrado el Sancto Arzobispo Don Rodrigo. Prosigue el abad, haciendo alusión a los efectos taumatúrgicos que, al parecer, éste tuvo, pues muchas gentes... affirman queste cuerpo deste bendito Señor a sido tenido por sancto desde la antigüedad, y que los enfermos sanaban a tocamiento deste sepulchro... para remedio de los affligidos se lleva la tierra de él y por esta causa su vulto y figura está tan mal-

Annales, op. cit., T. II, Appendix, p. 19, T. III, pp. 223224). Sobre su tumba se colocó una losa donde únicamente figuraba: $D^{\underline{a}} S^{\underline{a}}$. Acerca de este traslado, en tiempos del abad Estrada, nos dice Cordón: ... traslado los huesos de Da Sancha, madre de San Martín, del cimenterio detras de la capilla mayor en donde estuvo hasta su tiempo, a medio de la capilla mayor, donde oy esta y tiene estas letras: $D^{\underline{a}}$ Sancha (Cronología de los Abades, op. cit., fols. 67vto-68). En 1738, siendo abad Fr. Clemente Rodríguez, al enlosar de jaspe el pavimento de la Capilla Mayor, se abrió la urna depositándose los restos en una arquita de piedra y dejándola en el mismo sitio (E. de AGUILERA y GAMBOA, Marqués de Cerralbo, El arzobispo D. Rodrigo Ximénez de Rada y el Monasterio de Santa María de Huerta, Madrid, 1908, p. 165). Sin embargo, el padre de San Martín, Miguel Muñoz de Finojosa, mayordomo del infante D. Sancho, fue sepultado en el monasterio de Santo Domingo de Silos.

${ }^{26}$ En 1228, el obispo de Osma, Don Pedro, hace una serie de donaciones al monasterio y a su abad Juan ... a petición del Sr. Arzobispo D. Rodrigo quien también dio en tiempo de este abad los dos cuerpos santos que le dio Inocencio III cuando fue al Concilio Lateranense que el Libro Antiguo de los Entierros dice: estan sepultados entre el sepulcro del Santo Arz(obis)po que es el nicho baxo de la capilla mayor del lado del Evangelio y el sepulcro de San Martín que estuvo en medio de la capilla junto a la grada del Altar Mayor... (C. CORDÓN, Cronología de los Abades, op. cit., fol. 54). Sobre todo lo que aconteció con los traslados del cuerpo de don Rodrigo y la apertura de su sepulcro, vid. VV.AA., Vestiduras pontificales del Arzobispo Rodrigo Ximénez de Rada. Siglo XIII. Su estudio y restauración, Madrid, 1994. trasladada de fuera ${ }^{27}$. Por último, recuerda que siendo él niño, los Canónigos de Toledo pusieron en duda que el cuerpo del arzobispo se encontrase en Huerta, por lo que el abad fray Bartolomé Enríquez, para confirmarlo, intentó abrir el sepulcro, con ayuda de unas palancas, lo que motivo la destrucción de unas letras de oro que había en la junta ${ }^{28}$.

Dicho sepulcro se encuentra actualmente a los pies de la nave meridional (Lám. 1, F), apoyado sobre tres de los cuatro leones citados, trasladado a este lugar en el siglo XVII, al renovarse el presbiterio y labrarse los nuevos lucillos y urnas. Este sarcófago permaneció como memoria del ilustre personaje cuya figura, aunque muy desgastada, aparece revestida de pontifical en el frente de la yacija con una curiosa disposición del yacente ${ }^{29}$ (Lám. 3).

La iglesia de Huerta también fue panteón de los Condes de Medinaceli y sus familiares. La primera referencia documental que conservamos de este hecho aparece, aunque de forma imprecisa, en el testamento de Bernal de Bearne, I Conde de Medinaceli, otorgado el 3 de agosto de 1381 en Badajoz: et mando que, sy mi finamiento acae-

${ }^{27}$ L. de ESTRADA, De la fundación del Monasterio de Huerta, noticias del arzobispo de Toledo Don Rodrigo, de su cuerpo y sepulcro en dicho monasterio, Biblioteca de la Real Academia de la Historia, Col. Jaime de Villanueva, III, Sg. 9-4560; Id., "De origine Monasterii Hortensis... (c. 1580)", L. ESTEBAN, (Coord.), IV Centenario de Fray Luis de Estrada, Monasterio de Santa María de Huerta, 1983, pp. 387-395; F. GUTIÉRREZ BAÑOS, "Sepulcro de don Rodrigo Jiménez de Rada", Monjes y Monasterios, op. cit., p. 385.

${ }^{28}$ La inscripción decía: HIC IACET DOMINUS RODERICUS, FELICIS RECORDATIONIS ARCHIEPS. TOLETANUS (L. de ESTRADA, “De origine Monasterio", op. cit., pp. 387-395).

${ }^{29}$ El Marqués de Cerralbo justifica esta posición porque el sepulcro habría estado incrustado en un escaso hueco que, luego, engrandeciéndose mucho, constituyó una de las dos cámaras sepulcrales de los Duques de Medinaceli (El arzobispo D. Rodrigo, op. cit., p. 137). 
ciere, que me enterren en Santa María Dorta ${ }^{30}$. En la centuria siguiente son varios los miembros de esta familia que continúan la tradición, ordenando, ahora sí de forma taxativa, ser enterrados en la capilla mayor. Así, en el testamento de Juana Sarmiento, condesa de Medinaceli y esposa de Luis de la Cerda, dado el 27 de enero de 1435 en Medinaceli, se dice: Primeramente, ordeno $e$ mando... que mi cuerpo sea sepultado en el monasterio de Santa Maria de Huerta, en la capilla del coro, çerca de donde está sepultado el arzobispo don Rodrigo... ${ }^{31}$. Mientras que su marido, Luis de la Cerda, III conde de Medinaceli, hace lo propio en su testamento de 6 de agosto de 1447, cuando manda ser enterrado en la capilla mayor, junto a sus abuelos, su padre y su mujer, donando, además, una importante cantidad de dinero para reparar la iglesia: Otrosy mando ... que mi cuerpo sea enterrado e sepultado dentro de la capilla mayor del monasterio de Santa María de Huerta, çerca de donde están sepultados mis abuelos e el conde don Gaston, mi padre, e la condesa donna Juana Sarmiento, mi muger. E mando que den a la dicha iglesia diez mill maravedís para reparo della $a^{32}$ (Lám. 1).

Según la documentación, hubo otros enterramientos en la iglesia, aunque con un emplazamiento confuso. La tradición recoge que en el brazo Sur del transepto se abrían tres lucillos; en el central, estuvo enterrado Martín Muñoz, sobrino de San Martín, y uno de los personajes más destacados por sus donaciones en el proceso constructivo del monasterio, concretamente en la fábrica del refectorio y su panda ${ }^{33}$. En

-

${ }^{30} \mathrm{M}^{\mathrm{a}}$ L. PARDO RODRígueZ, Documentación del Condado de Medinaceli (1368-1454), Soria, 1993, pp. 228229.

${ }^{31}$ Id., pp. 379-381, especialmente p. 379.

${ }^{32}$ Id., pp. 460-467, especialmente p. 460.

${ }^{33}$ Este generoso Cavallero emprehendio la fabrica del Refectorio baja. Obra verdaderamente magnifica y digna de la potencia de un rey. Sería por los años que se hallaba en el valimento de Mayordomo mayor del Rey Don Enrique los laterales, se alojarían los cuerpos de dos de sus hijos (Lám. 1, E y Lám. 4).

Sin embargo, esta disposición de lucillos en el brazo del transepto opuesto al del claustro no era habitual en la topografía de un monasterio cisterciense, ya que el hueco central se correspondería con la Puerta de Difuntos $^{34}$. Quizás lo más probable es que, en un primer momento, a los restos de Martín Muñoz y de sus hijos se les diera sepultura en la panda del refectorio, en los arcos que dan al vergel, para después pasarlos al interior del templo, una vez cegadas las arquerías del claustro y remodelado

porque el año de 1223 se hallo una donacion de su hijo Don Diego Martin al abad Juan Gonzalo de dar 100 aureos a cuenta de los 1500 que su padre D. Martin Muñoz avia mandado para la fabrica del Refectorio. Y aunque las tablas dicen que aiudaron sus hijos, no consta por instrum(en)to mas que de este referido. Murio D. Martin Muñoz en una batalla contra Moros con dos hijos suios. No se dice donde tuvo su sepulcro donde ahora esta la puerta del cementerio y para abrirla se pasaron sus huesos a los arcos colaterales de sus hijos. El epitafio dice: "En estas sepulturas iacen los muy nobles cavalleros D. Martin de Finojosa y sus dos hijos que fueron ricos homes que ganaron mucha tierra de Moros y murieros en servicio de Dios y del Rey en una batalla, adonde aviendo hecho el padre y los dos buenos hijos cosas bien señaladas, los cercaron gran muchedumbre de Moros y pudiendose escapar los dos Mancebos, quisieron morir delante de su padre. Y después de aver muerto muchos infieles y recivido grandes heridas murieron los tres allí juntos año de 1250 reynando D. Fernando el S(an)to. Estos hicieron el Refectorio grande. Yacen aqui también ruy Diez de Finojosa y D(o)n Juan Diez su hijo"... (C. CORDóN, Cronología de los Abades, op. cit., fols. 49vto-50; Tumbo de todos los privilegios reales y pontificios, arriendos, foros, apeos, donaciones y otros papeles y escripturas que se hallan en este archivo y que pertenecen a la hazienda, exempciones $y$ libertades de este insigne y real monasterio de Huerta, Ms., Archivo de Huerta, 1666-1672, fol. 146, nº 4).

${ }^{34}$ La que hoy vemos es en arco de medio punto y da acceso a la capilla del Relicario, realizada en tiempos del abad Fray Vicente Martínez (1747-1750). Asimismo, Cordón recoge la noticia de que el abad Luis de Estrada (1557-1560): ... abrió la puerta del crucero que sale al cimenterio que el hizo... (Cronología de los Abades, op. cit., fols. $\left.67 \mathrm{vt}^{\mathrm{o}}-68\right)$. Lo más probable es que éste la hiciera más grande. 
el brazo sur del transepto con la realización de la Capilla del Relicario ${ }^{35}$.

Tampoco tenemos constancia de si en las naves hubo arcosolios como en otros templos ${ }^{36}$, aunque esto no es probable ya que, cuando en 1632 peinan las naves laterales para darles mayor anchura, pues resultaban muy angostas, no se habla de ningún impedimento de este tipo ${ }^{37}$.

\subsection{Pórtico/ Galilea}

Desde la radical prohibición a la clara tolerancia del enterramiento en el interior de las iglesias, el espacio de los pórticos o galileas $^{38}$, normalmente en las puertas prin-

\footnotetext{
${ }^{35}$ A. Ponz vio un letrero sobre la puerta del refectorio en el que se decía: DON MARTIN DE FINOJOSA $Y$ SUS HIJOS RICOS HOMES QUE MURIERON EN SERVICIO DE DIOS, Y DEL REY EN UNA BATALLA CONTRA MOROS. ESTOS NOBLES CABALLEROS HICIERON ESTE REFECTORIO CON ESTE LIENZO DEL CLAUSTRO, Y DIERON MUCHOS Y RICOS DONES Y HEREDAMIENTOS, COMO PARECE POR ESCRIPTURAS. YACEN ESTOS CABALLEROS EN DOS ARCOS, QUE ESTAN JUNTO LA CAPILLA DE LA MADALENA (Viage de España en que se da noticia de las cosas más apreciables, y dignas de saberse, que hay en ella, Tomo XIII, Madrid, 1788, reed. Madrid, 1972, p. 54). Manrique también hace referencia a estos tres personajes, fallecidos en un combate en 1250, que contribuyeron a la ingente fábrica del refectorio con los trofeos ganados a los sarracenos en tiempos del Rey Fernando (Annales, op. cit., T. II, Appendix, p. 20).

${ }^{36}$ Vid. al respecto I.G. BANGO TORVISO, “El espacio para enterramientos", op. cit.., p. 116.

${ }^{37}$ En el trienio del abad Manuel de Cereceda (1632-1635): ... se peynaron las dos naves colaterales de la Yglesia con la renta que dexo para esta y otras obras Fr. Francisco de San Bernardo (C. CORDÓN, Cronología de los Abades, op. cit., fol. $\left.75 \mathrm{vt}^{\mathrm{o}}\right)$. Dicha renta fue de 7.000 ducados de plata, destinados a sufragar obras de la iglesia, entre las que se preveía hacer una girola que no llegó a materializarse. El peinado consistió en rebajar los muros unos 40 ó $50 \mathrm{cms}$ en los tres tramos más orientales, puesto que sobre los dos primeros ya se había construido el coro y el sotocoro con sus abovedamientos correspondientes. Incluso, Manrique se hace eco de dichas obras cuya finalidad era hacer más "gratas" las naves que, hasta entonces, eran muy angostas (Annales, op. cit., Tomo II, p. 33).

${ }^{38} \mathrm{La}$ introducción de los usos cluniacenses entre los monjes hispanos, a partir del siglo XI de manera
}

cipales de los templos, fue el ámbito elegido para dar sepultura a los privilegiados de la sociedad $^{39}$. Entre los monasterios cistercienses disponemos de otros ejemplos, como el ya referenciado de Cîteaux o Alcobaça ${ }^{40}$, o los españoles de Poblet, Huelgas o San Andrés de Arroyo, que sirvieron de enterramiento a importantes personajes ${ }^{41}$. En Huerta, junto a la puerta occidental, quedan huellas de un arco apuntado, vestigio del apoyo de una bóveda, y los huecos de los mechinales donde se alojaban las cabezas de las vigas para la cubierta de un posible pórtico o nártex, en el que quizás hubo sepulturas $^{42}$ (Lám. 1, G). Salazar y Castro

generalizada, contribuyó a denominar "galilea" al pórtico occidental de las iglesias monasteriales. Al final el término dejó de ser exclusivo de lo monástico y sirvió sólo para indicar una estructura de pórtico, más o menos amplio, a los pies del templo (I. G. BANGO TORVISO, "El espacio para enterramientos", op. cit., p. 108).

${ }^{39}$ Como ejemplos más representativos tenemos el de San Zoilo de Carrión de los Condes, San Salvador de Oña o San Facundo y San Primitivo de Sahagún (Id., p. 108; Id., "Atrio y pórtico en el románico español: concepto y finalidad civico-litúrgica", Boletín del Seminario de Estudios de Arte y Arqueología, 1975, pp. 175188 , las referencias a la función funeraria especialmente en pp. $178-180$.

${ }^{40}$ Los reyes portugueses, que habían impulsado la construcción de este gran monasterio cisterciense entre 1178 y 1252, no consiguieron obtener autorización para enterrarse en el interior del templo, teniendo que conformarse con un panteón en el pórtico occidental (A. DIMIER, L'art cistercien hors de France, Sainte-Marie de la Pierre-qui-vire, 1971, pp. 256-298; I.G. BANGO TORVISO, "El espacio para enterramientos", op. cit., p. 110).

${ }^{41}$ M. AUBERT, L'architecture cistercienne, op. cit., Vol. I, pp. 364-365; I.G. BANGO TORVISO, “El ámbito de la muerte", op. cit., p. 324; Id., "El espacio para enterramientos", op. cit., p. 110.

${ }^{42}$ Para C. de la Casa ("El proyecto de restauración del monasterio de Santa María de Huerta (Soria). Aspectos arqueológicos", Revista de Arqueología, no 54, 1985, pp. 49-55) la galería encontrada, destruida por el frente que hoy ocupa la hospedería, es románica por el tipo de sillares, las marcas de cantero y un dinero de vellón de Alfonso I el Batallador hallado en la excavación. Durante unas excavaciones realizadas en los años ochenta se encontró en el ángulo N.E. de dicha galilea una tumba de lajas, fechada en el siglo XIII, aunque sin 
ubica aquí el enterramiento de Doña María Manrique, hija de don Manrique de Lara -Señor de Molina y vizconde de Cardona- y casada con Diego López de Haro, que vivió a fines del siglo XII y principios del siguiente. Elegido este lugar por humildad, se trataba de una losa llana de alabastro con el bulto en relieve trasladado, por deseo de Carlos V, al capítulo junto a los enterramientos de sus padres ${ }^{43}$.

\section{ENTERRAMIENTOS EN EL CLAUSTRO}

En la actualidad no resulta sencillo definir con precisión cúales fueron los enterramientos del claustro, ya que prácticamente ninguno ocupa su lugar original ${ }^{44}$. $\mathrm{Si}$ a ello añadimos que la mayoría de sus epígrafes ya habían desaparecido en época moderna y que los letreros que los sustituyeron también se han perdido, las dificul-

restos oseos (C. de la CASA, M. DOMENECH y E. TERÉS, "Arqueología hortense II: excavaciones 1982-1984", Cistercium, 190, 1992, pp. 555-593).

${ }^{43}$ Mandose sepultar Doña María Manrique en el monasterio de Huerta, eligiendo por humildad, no el capítulo donde yace su madre, sino el sitio menos obstentoso de aquella casa, que fue a la puerta de la Iglesia, para que todos hollasen su cuerpo. De esta moderacion Christiana sacaron los antiguos el quento que se refiere el libro del Conde D. Pedro, de aver cometido esta Princesa cierto delito de fragilidad, para cuya satisfacción eligio tan humilde sepulcro; y siguiendole Ambrosio de Morales, Argote de molina, y el Valerio de las Historias dicen, que entrando Carlos $V$ en la Iglesia de Huerta, reparó la losa llana de alabastro con el bulto de relieve, que significava esta princesa: y que aviendo sabido cuyo era aquel sepulcro, y oido el quento porque le eligio en tal lugar, mando que le trasladasen al capitulo con sus padres, pues ya avia hecho bastante penitencia (L. de SALAZAR y CASTRO, Historia Genealógica de la casa de Lara, Madrid, 1696, Tomo I, Lib. III, pp. 127-128, reed. Bilbao, 1988).

${ }^{44}$ Sólo se conservan cuatro nichos funerarios: dos en la panda del mandatum y dos en la del refectorio, si bien no tenemos la certeza absoluta de que éstos sean sus emplazamientos primitivos, ni siquiera que fueran realizados para las personas finalmente inhumadas. A esto hay que añadir que los sepulcros que hubiera en los intercolumnios desaparecieron cuando se cegaron las arquerías del claustro entre 1695 y 1698, en tiempos del abad Pedro de los Herreros (J.L. HernANDo GARRIDO, “Rigor formal”, op. cit., p. 191). tades para una certera atribución son aún mayores ${ }^{45}$. Solamente disponemos de noticias documentales acerca de los comitentes que, con sus aportaciones, contribuyeron a levantar algunas dependencias, permitiéndonos conocer el proceso cronoconstructivo del monasterio. Como ya he comentado, el hecho de que el claustro de Huerta reciba el nombre de "Claustro de los Caballeros" viene determinado porque en él se acogieron los cuerpos de aquellos hombres que, con sus intervenciones en las guerras o por sus donativos al monasterio, se hicieron merecedores de ello ${ }^{46}$.

En la panda del capítulo existió un letrero, recogido por A. Ponz, en el que se especificaban las condiciones requeridas para que fueran inhumados en ella los caballeros de cuenta o personas de grande estado..., entre las que aparecían como requisito indispensable ser noble, partir para la guerra contra los moros y dejar sus posesiones al monasterio ${ }^{47}$.

\footnotetext{
${ }^{45}$ Prueba de ello es la falta de unanimidad entre las diferentes fuentes documentales a la hora de localizar los sepulcros en las respectivas pandas. Sobre el particular vid. en la Colección Salazar y Castro (Real Academia de la Historia de Madrid): Relación de los sepulcros que hay en el monasterio de sancta maria de huerta de la orden del Cistel (Soria), F-40, fols. 64-79; Memoria de los Señores de la Casa de Hinojosa que estan enterrados en esta Casa de Nuestra Señora la Real de Huerta, legajo C, carpeta 13, n. 2. y Noticias historicas de Huerta y copia de algunas insripciones sepulcrales, C-41, fol.s. 417-424.

${ }^{46}$ Esta circunstancia también se da en otros monasterios femeninos de la orden como son los pórticos laterales de Las Huelgas de Burgos o de San Andrés de Arroyo, donde, por las mismas razones expuestas, recibieron sepultura los nobles.

${ }^{4}$ La muy antigua y noble costumbre que los caballeros hidalgos y ricos homes de toda esta comarca de Castilla y Aragon usaban y tenian cuando iban a la frontera de moros, o a otra cualquiera guerra era que venian a velar y a confesarse, y a ordenar sus testamentos, y a encomendarse a las oraciones de todos los Religiosos de esta Santa Casa con gran devoción, y enviaban pitanza para el Convento y cirios para el altar de la Capilla que tenian devocion; y el Abad, y los Monges hacian procesion y celebraban en aquel altar Misa de la Santisima Trinidad, y rogaban a Dios les dexase
} 
En este sentido, no solamente eran elegidas las abadías como morada eterna, sino también los claustros de los conjuntos catedralicios se convertirán en auténticos cementerios $^{48}$. Acerca de esto, debemos recordar los "Estatutos de Ordenación sobre Enterramientos" de la catedral de Sigüenza, redactados en 1353 y y recogidos en el Libro de la Cadena. En ellos se destina cada una de las pandas a los diversos estamentos sociales $\mathrm{y}$, así, reunidos el deán y cabildo deciden que: ... la primera Panda [Panda del Capítulo], de la dicha Claustra, que es ante la puerta de la Capilla de Santa Liberata, sea para enterramientos e personas de la dicha Iglesia. E para Caballeros...; que la otra Panda [Panda del Mandatum], que es ante la Capilla de Santa María Magdalena e de Santa Catherina, que sea para enterramientos de los Canónigos, Racioneros e Compañeros de la dicha Iglesia e para escuderos hijosdalgos...; la tercera Panda [Panda Oeste], según se entre después de ésta, que sea para parientes e parientas de los beneficiados de dicha Iglesia...; la cuarta Panda [Panda Norte] allende de ésta, que sea para los enterramientos de los otros parientes de los de la Iglesia e para criados e otros estraños... ${ }^{49}$.

vivir, y acabar en su santo servicio y tomada la bendicion del Abad, partian para la guerra. Asimismo desde la fundacion de este Monasterio se guardo siempre inviolablemente y se tuvo y tiene en costumbre que en el paño del claustro que va delante del capitulo, donde yacen los Caballeros de cuenta, que no se debe enterrar ninguno, si no fuere persona de grande estado, o que muera en pelea de moros, y que herede, $y$ de algunas posesiones al Monasterio. $Y$ los Condes y ricos homes que estan enterrados en este claustro, era costumbre que traian con su cuerpo un dosel de oro, o de seda, para poner sobre su sepultura y el caballo o mula en que venia se quedaba para el Monasterio, y su cama para la enfermeria y una taza, o copa de su aparador habia de traer y traian para un caliz; $y$ de esta manera se enterraban todos los caballeros que estan en este claustro y ansi se han de enterrar los que aqui escogieran sepultura (A. PONZ, Viage, op. cit., pp. 6364).

${ }^{48}$ Remito nuevamente al artículo de E. Carrero Santamaría, "El claustro funerario", op. cit.

${ }^{49}$ Archivo de la Santa Iglesia Catedral de Sigüenza, Libro de la Cadena, fols. 37-38; M.C. MUÑOZ PÁRRA-
En Huerta, a diferencia de otras casas cistercienses, parece claro que existió una mayor flexibilidad en las estrictas prohibiciones para ser enterrado en el monasterio, probablemente ante la necesidad que la comunidad tenía de recibir donaciones, lo que supuso un elevado número de enterramientos en el claustro. Por ello, algunos personajes supeditan enterrarse en el monasterio a condición de que se cumplan ciertas claúsulas. Así, el Conde Pedro de Molina, en 1181, hace cuantiosas donaciones para que se construya un monasterio en Arandilla donde se quiere enterrar y, si ello no se lleva a cabo, dispone que su cuerpo sea trasladado a Huerta ${ }^{50}$. Otros convienen que en la abadía hayan recibido sepultura personajes ilustres o de probada santidad, como en el caso de Munio Sancho quien, tras hacer una importante donación para la construcción del dormitorio hortense, solicita ser enterrado junto al abad Martín y si ello no fuera así, poder elegir otro lugar ${ }^{51}$.

GA, La catedral de Sigüenza. (Las fábricas románica y gótica), Guadalajara, 1987, pp. 361-362.

${ }^{50}$ La donación consistía en cuatrocientas ovejas, cuarenta vacas, diez yeguas y cuanta heredad pudiesen arar dieciseis yugadas de bueyes de año en año, junto con la heredad de Arandilla para que se edificase un monasterio en el que se manda enterrar. Otorga también dos mil morabetinos, pero si muriese antes de que estuviese acabado el monasterio o de haber donado las cabezas de ganado y heredades citadas, era su voluntad que los monjes de Huerta lo sepultasen en Arandilla, donde, erigido un altar, se habían de celebrar sufragios por su alma durante sesenta días, debiendo su sucesor entregar tres mil maravedíes para la continuación de la fábrica del monasterio. Caso de no cumplir su voluntad, o de ser insuficiente la donación para construir el monasterio de Arandilla, su cuerpo sería trasladado al monasterio de Huerta, para el que quedaría Arandilla y todo cuanto le hubiese dado (J. A. García LuJÁN, Cartulario, op. cit., Doc. no 43, pp. 68-70; C. Cordón, Cronología de los Abades, op. cit., fol. 43).

51 J.A. GARCÍA LUJÁN, Cartulario, op. cit., pp. 52-53; A. MANRIQUE, Annales, op. cit., T. III, p. 23; C. CORDÓn, Cronología de los Abades, op. cit., fol. 42vto. En la Relación de los sepulcros, fol. $67 \mathrm{r}$ se dice que quienes hicieron el dormitorio fueron los Condes de Molina 
Los enterramientos del claustro de Huerta se alojaron indistintamente en los muros externos del perímetro y bajo las arquerías que dan al vergel. Sin embargo, éstos últimos se trasladaron o perdieron cuando se cegaron los vanos para reforzar los muros al construirse el claustro alto $\left(\right.$ Lám. 5) ${ }^{52}$; llegando, incluso, a reutilizarse huecos de época medieval, como puertas y el armariolum. Fue entonces, quizás, cuando se colocaron los letreros que recoge Ponz, como memoria de dichos enterramientos.

A continuación vamos a referenciar los lugares donde hubo sepulturas que, tras el análisis de la documentación, podemos asignar con cierta seguridad a los diversos personajes.

Comenzando por la panda del Capítulo (Figs. 1 y 2), el primer hueco que encontramos es el que, en origen, fue armariolum, formado por un arco de medio punto que cobija otros dos apuntados, apoyados sobre columnas con capiteles de crochets (Lám. 1, no 1, Lám. 2 y Lám. 6). Este hueco sirvió como enterramiento a Pedro de Manrique (+1202), Conde de Molina ${ }^{53}$. Referente

(A. GARCía Flores, "Espacios funerarios", op. cit., p. 223, n. 84).

${ }^{52}$ A. García Flores, "Espacios funerarios", op. cit., p. 225, n. 95.

${ }^{53}$ En el muro del fondo del lucillo aún se conserva una inscripción, en caracteres góticos, referente al conde:

LUX PATRIAE/ CLIPEUS POPULI/ GLADIUSQUE MALORUM/ SUB PETRA PETRUS TEGITUR COMES-

INCLITUS ISTA/ OBIIT/ III IDUS/FEBRUARIUS/ ERA/M/CC/XL

Inscripción traducida en V. GARCÍA LOBO y $\mathrm{M}^{a} \mathrm{E}$. MARTín LÓPEZ, “La publicidad en el Cister”, op. cit., p. 60. Sánchez Ameijeiras (Investigaciones iconográficas, op. cit., p. 28) cree que se labraron, en el segundo cuarto del siglo XIII y para familiares de la Casa de Molina, este arco geminado y el que está junto a él, inspirados ambos en el vano del capítulo. En el que ahora nos ocupa ubica los enterramientos de Almerique, conde de Molina (+1166), Armesinda, su mujer, condesa de Narbona, y su hijo don Manrique, que habían sido trasladados allí desde Arandilla. Para Hernando Garri- a su ubicación tanto Manrique ${ }^{54}$ como Ponz coinciden en situarle en el mismo lugar:

En el paño del Claustro de poniente ${ }^{55}$ se lee que alli yace don Pedro Manrique, conde de Molina y su mujer doña Sancha, hija del rey de Navarra, bisnieta del gran Rui Diaz de Vivar, la que en primeras nupcias se dice caso con don Gastón, vizconde de Biarne, de quien no tuvo hijos, y en segundas con don Pedro Manrique quien murio el año 1202. Encima de la sepultura hay un Santiago a caballo... ${ }^{56}$.

El siguiente hueco, claramente encajado sobre un vano anterior, está formado por un arco excesivamente apuntado, que cobija un gran óculo y doble arquillo trilobulado sobre columnas y capiteles muy desgastados (Lám. 1, nº 2, Lám. 2 y Lám. 7). En él fueron sepultados otros miembros de la Casa de Molina. Respecto a este nicho y a su tablilla, A. Ponz dice:

Inmediato a la entrada de la iglesia se lee: "Aqui yace el Conde don Almerique, conde de Molina y vizconde de Narbona, hijo del Conde Don Pedro, y de la Infanta Doña Sancha, que por no tener hijos, sucedió en su Estado su hermana Doña Sancha Gomez, muger de Don Gonzalo Pérez, que fueron Señores de Molina; $y$ este Conde, y el Conde Don Pedro que mató al Moro Zafra, eran hermanos... Asimismo esta

do ("Rigor formal", op. cit., p. 191) el armariolum fue reutilizado para el sepulcro de Pedro Manrique, segundo Conde de Molina (+1223).

${ }^{54}$ Annales, op. cit., T. II, Appendix, p. 18.

${ }^{55}$ Aunque podríamos interpretarlo como la panda occidental, debe referirse, quizás por confusión, a la panda del capítulo. Para Sánchez Ameijeiras (Investigaciones iconográficas, op. cit., pp. 28-29) esta expresión debe interpretarse como que estaba enterrado en las arquerías exteriores de la panda.

${ }^{56}$ Viage, op. cit., p. 62. Cerralbo coincide con Ponz $y$ añade que en esta tumba hubo un pequeño altar en el que se expuso un "Santiago" y se decía Misa en su festividad (E. de AgUILERA Y GAMBOA, El Arzobispo D. Rodrigo, op. cit., p. 202). No debemos olvidar, como nos dicen los tableros, la relación entre Santiago Matamoros y los caballeros que intervinieron en la Reconquista. 
aqui sepultado don que fue señor de Molina... Paso este noble caballero de esta vida año del Señor de $1245^{\prime \prime 57}$.

Este Conde Don Pedro (+1223) fue hijo del Segundo Conde de Molina, del mismo nombre, esposo de Doña Violante. Sobre dicho personaje, Ponz recogió la inscripción de otra tablilla en la que se relataba el tributo que, para alcanzar la vida eterna, los caballeros debían pagar, yendo a la guerra santa contra los musulmanes ${ }^{58}$ :

Aquí yace el Conde Don Pedro Manrique, que nos dio la Torre de Zafra, que es en término de Alarcón, y nos dio la presa, y molinos, y batan, y la casa con la heredad, y con su capilla de Santiago, que está ribera de Júcar, cerca de Albadalejo del Cuende, que es cerca de Cuenca; y este valeroso Conde mató al Moro Zafra, que era un moro muy descomunal, que tenía de ojo a ojo un palmo, y otras figuras muy fuertes, que no había home que con él pelease, que no le matase; $y$ el dicho Señor Conde encomendose a la Virgen Santa María de Huerta, y ofreció el su cuerpo, y prometió la dicha Torre, si él matase a Zafra, y a dicha su Capilla de Santiago con toda su heredad, y término, y ayudándole Dios nuestro Señor, y la Virgen María el buen Conde mató a Zafra y dio la Torre a este monasterio; la qual dicen hoy la Torre del Monge, que es término de Alarcon, cerca de Villar del Sauce, y la presa con los molinos, y la casa con su término, y con su Capilla de Santiago. Pasó de esta vida el año de $1223^{59}$.

-

${ }^{57}$ Viage, op. cit., p. 59; también A. MANRIQUE, Annales, op. cit., T. II, p. 428. Para Sánchez Ameijeiras (Investigaciones iconográficas, op. cit., p. 28) los enterrados fueron don Manrique, Conde de Molina $(+1233)$ y su cuñado Gonzalo Pérez de Lara (+1245), fechando este arco también en el segundo cuarto del siglo XIII.

${ }^{58}$ Esta claro que todos estos relatos nos hablan, como lo ha llamado I. Bango, de los sones épicos de una sociedad caballeresca ("Un mundo para la eternidad", Monjes y Monasterios, op. cit., p. 311).

${ }^{59}$ Viage, op. cit., pp. $59-60$.
Prosiguiendo la panda hacia el Norte, encontramos la puerta de la antigua sacristía medieval, destruida en 1599 para construir la actual. Cerralbo es el único autor que ubica en este lugar los restos de Violante $^{60}$ (Lám. 1, no 3 y Lám. 2).

Los tres huecos correspondientes a los vanos de la Sala Capitular, también se habilitaron como enterramientos cuando, a partir del s. XVI, dejó de ser utilizada ${ }^{61}$. En el meridional quizás estuvieron depositados los restos de parientes de San Martín, concretamente los de Gil Garcés ${ }^{62}$, Diego Muñoz y García Muñoz, caballeros de Fernando III, fallecidos en 1256 (Lám. 1, no 4 y Lám. 2) ${ }^{63}$.

${ }^{60}$ El arzobispo D. Rodrigo, op. cit., p. 201.

${ }^{61}$ Sánchez Ameijeiras (Investigaciones iconográficas, op. cit., p. 26) cree que el vano septentrional debió cegarse en el primer tercio del siglo XIII, para servir de complemento mural del sepulcro de Pedro de Bera. Es inverosímil pensar que la comunidad de Huerta en pleno siglo XIII cegase uno de los vanos de la estancia más importante del monasterio, después de la iglesia. No debemos olvidar que el capítulo cumplía una función fundamental en la vida común, servía para reunir en él a los monjes después de la misa matinal, que el abad comentara la regla y, finalmente, realizar la confesión pública. Además, a través de las ventanas del capítulo, los días festivos los conversos oían desde la panda el sermón que pronunciaba el abad. Por tanto, no se puede creer que en un momento en el que los conversos tenían una gran importancia en la vida monástica, uno de los vanos del capítulo se dedicara a otra cosa que no fuera la funcionalidad tradicional. Lo más probable es que el vano se cegase cuando los usos de la comunidad habían cambiado y la figura del converso caído en desuso, seguramente a partir del siglo XVI.

${ }^{62}$ Un Gil Garcés hace testamento en julio de 1201, por el cual promete al abad Jimeno varias donaciones y enterrarse en el monasterio de Huerta (J.A. GARCÍA LUJÁN, Cartulario, op. cit., p. 114). Cordón dice sobre este personaje: De este se halla una promesa hecha al Abbad Gimeno el año de 1200 de enterrarse en Huerta ofreciendo la vigessima parte de lo que el Rey le diese, para la fabrica del Monasterio... (Cronología de los Abades, op. cit., fol. $\left.50 \mathrm{vt}^{\mathrm{o}}\right)$.

${ }^{63}$ En el letrero reproducido por A. Ponz no se especifica la ubicación del sepulcro, sólo decía Aqui yacen sepultados los nobles caballeros Gil Garces y Don Diego 
Según Cerralbo, en el vano correspondiente a la puerta del Capítulo estuvo enterrado Roldán Pérez de Medrano $(+1293)^{64}$ y en el hueco septentrional, donde áun se conserva la inscripción, claro ejemplo de la pretenciosidad que, en ocasiones, demostraba la nobleza, descansaron los restos de don García de Bera $(+1265)^{65}$, hijo

Muñoz y don Garcia Muñoz su hermano que fueron nietos del generoso caballero Nuño Sanchez el Noble. Estos esforzados caballeros hicieron cosas señaladas por las armas en tiempo del Rey don Fernando, que gano a Sevilla y a Cordoba y se hallaron en muchas batallas, que a los moros se dieron. Pasaron de esta vida el año de 1256 (Viage, op. cit., pp. 60-61).

${ }^{64}$ El Arzobispo D. Rodrigo, op. cit., p. 202. Como veremos más adelante, Ponz sitúa esta sepultura en la panda Norte, entre "el refectorio y el dormitorio".

${ }^{65} \mathrm{La}$ inscripción hace referencia a este caballero, que había combatido contra los moros a las órdenes del rey D. Jaime y tomó el hábito en el monasterio en 1255, a los 50 años de edad:

HEC METRA GARSIE DE BERA SCRIBERE CONOR

PER QUEM CREVIT HONOR EQUITUM, CELTISQUE SOPHIE

MAGNANIMUS MAURIS FUIT ET FERUS HOSTIBUS HOSTIS

ET, VELUTI NOSTRIS, UT OVIS PLACABILIS AGNIS

CONSILIO FRETUS, PACIS VEL TEMPORE GUERRE

ASPERA PERFERRE DIDICIT, VEL PROSPERA LETUS

CUI CIBUS ET VESTRES, MULORUM GREX ET EQUORUM

ET RONCINORUM SUNT DE DARE GRANDIA TESTES

ORTA VIRUM TALEM, TANTUM PROCUL EXULE SORDE,

COMPUNCTUM CORDE, CULTUM TULIT AD MONACHALEM

RURSUS IN HAC TUMBA LEO TRUX ET BLANDA COLUMBA;

TRUX LEO LASCIVIS; SED BLANDIS UTPOTE CIVIS.

ERGO TUUM, CRISTE, DIGNARE ROGARE PARENTEM

NE SE TERRENTEM D(O)MI(N)UM LEO SENTIAT ISTE.

ANNO D(OMI)NI MCC.LX.V.XVII K(A)L(ENDAS) AUGUSTI

OBIIT DONNUS GARSIAS DE BERA.

Inscrpción recogida y traducida por V. GARCíA LOBO y Mำ E. MARTín LÓPEZ, “La publicidad en el de Pedro de Bera ${ }^{66}$ (Lám. 1, no 5, Lám. 2 y Lám. 8). Sin embargo, otras fuentes ubican estos sepulcros en el interior de la sala capitular. Así, en el umbral de la puerta se encontraban los enterramientos de Pedro de Cetina y Gil González de Cetina; en el interior de la estancia, en el lado septentrional estaban los de Pedro de Bera y su esposa, embutidos en el muro, y García de Bera y su esposa, en el pavimento, mientras que en el meridional se hallaban las de Gonzalo Pérez de Deza, su hijo Alonso González y otros familiares ${ }^{67}$.

La última estancia de la panda es la capilla de Profundis que, para Cerralbo ${ }^{68}$, tuvo otra puerta, abierta a comienzos del siglo XVII, sobre un panteón en el que yacían cuatro caballeros navarros, que sirvieron con el Conde de Foz a Enrique II, parientes del Arzobispo don Rodrigo. Ponz también se refiere a ellos, aunque ubicando su sepulcro en el lienzo del claustro que mira al mediodía, es decir en la panda meridional ${ }^{69}$ (Lám. 1, nº 6, Lám. 2 y Lám. 9).

Cister", op. cit., p. 60.
${ }^{66}$ Gran benefactor del monasterio quien, en 1202, había hecho una donación al abad Gimeno para las obras: ... pro redemptione anime sue et corporis sepulturam Ortense monasterium sibi retinent (J.A. GARCÍA LUJÁN, Cartulario, op. cit., pp. 116-117). Cordón (Cronología de los Abades, op. cit., fol. $52 \mathrm{vt}^{\circ}$ ) recoge que dio 200 alfonsinos de oro fino por estar el Monasterio con muchas deudas y falta de trigo con condición que si moría antes de pagarselos, le dixessen los ciento de Missas y los otros ciento entregassen a S. Martin y al obispo de Siguenza para limosnas... Sobre la fecha de ubicación de este sepulcro aquí, vid. nota 61 .

${ }^{67}$ Relación de los sepulcros, fols. 64-79.

${ }^{68}$ El Arzobispo D. Rodrigo, op. cit., p. 203; de la msima oponión son las Noticias históricas, fol. 421 vto$422 \mathrm{r}$.

${ }^{69}$ En el lienzo del claustro que mira al mediodía hay otros sepulcros y un tablero donde dice: En estas quatro sepulturas yacen enterrados los nobles caballeros Monsieur Pui de Ustante; y Monsieur Febus, y otros generosos de Francia, que por madado del Rey de Francia vinieron con el conde de Fox a servir y ayudar al rey D. Enrique II, de este nombre en la guerra, que con el rey D. Pedro su hermano tenia en el año de 1367 y despues en muchas batallas entre estos dos reyes hermanos, donde todos estos caballeros 
De igual modo, es difícil la identificación de los enterramientos en la panda del refectorio (Lám. 1 y Lám. 2). En el ángulo N.E., junto a la entrada de la Escalera Real, se abre un lucillo en arco apuntado sobre otro trilobulado en el que hay un sepulcro que, tradicionalmente, se atribuye a Nuño Sancho de Hinojosa, hermano de San Martín, y a su esposa, Doña Marquesa, quienes dieron una importante donación para la fábrica de la panda del refectorio. Sin embargo, contrastando las distintas fuentes se desprende que ambos estuvieron enterrados en el primer arco de esta galería que se abre al jardín ${ }^{70}$ (Lám. 1, no 7 y Lám. 2). Así, Cordón relata que a mas de Albalate y Albaladejo dieron también 1500 mencales para la fabrica del lienzo del claustro del Refectorio como lo dice la tabla que esta sobre su sepulcro, que es el primero de aquel lienzo azia el jardin, que hizo en vida para si y su mujer doña Marquesa, donde iacen dignos de eterna memoria y gloria y es el primero de los Finojosas, que se enterro en Huerta el año de 1206 en que murio $^{71}$. Vuelve a insistir más adelante sobre dicho emplazamiento: Esse año murio Munio hermano de S. Martín para Bienechor. Esta en el primer arco enfrente dela escalera y refectorio con su mujer $D^{\underline{a}}$ Marquesa que murio luego ${ }^{72}$. Ponz también la sitúa en dicho lugar, pues al referirse a la de Roldán Pérez de Medrano dice que enfrente de ella hay una tablilla donde se lee: En esta sepultura yace Nuño Sancho el Noble, Rico Home de Finojosa, y

franceses mostraron bien el esfuerzo gran de sus generosos corazones... y estos nobles caballeros que aqui estan enterrados fueron parientes de este conde de Fox y primero conde de Medinaceli. Pasaron de esta vida en el año 1380 (Viage, op. cit., pp. 56-57).

${ }^{70}$ Para hacernos una idea de cómo sería éste de Huerta, disponemos de un ejemplo conservado in situ en el claustro del monasterio de Villamayor de los Montes (Burgos).

${ }^{71}$ Cronología de los Abades, op. cit., fol. 48 vtº. Para García Flores ("Espacios funerarios", op. cit., p. 223) también estuvieron enterrados aquí sus hijos Martín y Adán Muñoz.

${ }^{72}$ Id., fol. 53 .
Doña Marquesa su muger, este caballero fue muy temido de los moros, y vencio muchas batallas de ellos, y hallose en la gran batalla, y cerco, que el rey Don Alfonso el VIII de este nombre puso sobre Cuenca quando la gano el año de 1176, donde este noble caballero hizo cosas señaladas por su ley y por su rey por lo qual su nombre sea loado, y su esfuerzo estimado. Todo lo que cupo en Cuenca de su parte lo dio a este monasterio de Huerta, y hoy dia habemos una granja, que se llama Albadalejo, cerca de Cuenca, y la casa de la moneda de Cuenca, y demas de esto nos dio mil quinientos mencales de oro para hacer este paño que esta junto al refectorio, donde esta el enterrado. Paso de esta el año de $1206^{73}$.

Por su parte, también Manrique relata sus victorias contra los sarracenos y las amplias donaciones que dió este personaje al monasterio de Huerta ${ }^{74}$.

Frente al sepulcro anterior, está el enterramiento de Roldán Pérez de Medrano, que Ponz ubica entre la puerta del refectorio y el dormitorio, en la segunda sepultura ${ }^{75}$ (Lám. 1, no 8, Lám. 2 y Lám. 10). En el lucillo contiguo fue enterrado Nuño Martínez $(+1263)^{76}$, señalero del rey Fernando III, que había luchado valientemente contra los moros $^{77}$ (Lám. 1, no 9, Lám. 2 y Lám. 10).

${ }^{73}$ Viage, op. cit., pp. $55-56$

74 Annales, op. cit., T. III, p. 467.

${ }^{75}$ En ella se leía: En esta sepoltura yace el noble caballero Don Roldan Perez de Medrano el qual paso de esta vida el año 1293 (Viage, op. cit., p. 810). Recogida por V. GARCíA LOBO y Maㅡ E. MARTÍN LÓPEZ, “La publicidad en el Cister", op. cit., p. 61.

${ }^{76}$ De él dice Cordón: Fue Munio Mar(tine)z Alferez de S. Fernando que esta enterrado enfrente del Refectorio junto a la puerta del Vergel y murio el año de 1263 (Cronología de los Abades, op. cit., fol. $50 \mathrm{vt}^{\mathrm{o}}$ ).

${ }^{77}$ En el letrero sobre su tumba se leía: Aqui yace sepultado el esforzado caballero Nuño Martínez que fue señalero (que agora se dice alferez) del rey Don Fernando el Santo; y en muchas batallas, y reencuentros que con los moros hobieron; este caballero mostro bien el esfuerzo de su gran corazon; y hizo cosas muy señaladas por aventurar la santa fe catolica, y servir a su rey: murio el año de 1363. (A. 
No hay constancia de sepulcros, ni material ni documental, en la Panda de la Cilla, aunque podríamos pensar que, al igual que en las otras pandas, sí existieron entre las arquerías ${ }^{78}$.

Por último, en la Panda del mandatum (Lám. 1 y Lám. 2), en al ángulo S.W., hay un hueco en alto, en arco de medio punto doblado que, tradicionalmente, se señala como enterramiento de la familia de Montuenga (Lám. 1, no 10 y Lám. 2). Probablemente fueron trasladados a este lugar, procedentes de las arquerías, según Ponz, al menos dos enterramientos, los de Gil Ruiz de Montuenga y Pedro Jiménez de Montuenga $^{79}$. En el lado oriental de esta panda, aún se conservan dos nichos, en arco de medio punto moldurado con baquetones, que se asocian, en el quinto tramo, con los enterramientos de Bugo y Gil Sánchez, arcedianos de Toledo, los quales hicieron este paño de claustro (Lám. 1, no 11 , Lám. 2 y Lám. 11), y con el de Don Ruselus, deán de Toledo, en el séptimo (Lám. 1, no 12, Lám. 2 y Lám. 12) ${ }^{80}$. Se trata de tres

PONZ, Viage, op. cit., pp. 55-56). Recogido asimismo por V. GARCíA LOBO y Maㅡ E. MARTíN LÓPEZ, "La publicidad en el Cister", op. cit., p. 60. Es evidente que Ponz se equivoca en cien años sobre la fecha de la muerte, pues si hubiera fallecido en 1363 , no podría haber estado al servicio de Fernando III.

${ }^{78}$ Según las Noticias históricas (fol. 423 vtº̄) sí se enterraron en esta zona algunos Montuenga. Quizás los caballeros no eligieron enterrrarse en esta panda por ser la menos frecuentada por los monjes (T. POLVOROSA LÓPEZ, Santa María la Real de Huerta, Santa María de Huerta, 1963, p. 71; J.M. MARTíNEZ FRÍAS, El gótico en Soria. Arquitectura y escultura monumental, Salamanca, 1980, p. 54; V. GARCÍA LOBO y Mํㅡ․ MARTíN LÓPEZ, “La publicidad en el Cister", op. cit., pp. 52 y 57).

${ }^{79}$ Asimismo, puntualiza que cerca de éstos yacen otros miembros de esta familia que fueron bienhechores del monasterio (Viage, op. cit., p. 58).

${ }^{80}$ Ponz señala que, próximo al primer arcosolio, existió un letrero con el siguiente texto: En esta sepoltura yace el dean don Ruselus de Toledo; $y$ en las otras sepolturas, que estan cerca de esa yacen dos arcedianos, que andaban siempre con el Arzobispo Don Rodrigo, y al uno decian Bugo y al otro Don Gil Sanchez, los quales hicieron sepulturas que quizás, en origen, estuvieron alojadas en las arquerías del vergel y después cambiadas a los mencionados arcosolios que conservamos junto al ángulo S.E.

A modo de conclusión, la iglesia y el claustro de Huerta se convirtieron en un verdadero panteón de nobles, pertenecientes a una sociedad que había elegido a los monjes del Císter como custodios de sus sepulcros para que, con sus oraciones, intercediesen ante el Juez Supremo el día del Juicio Final. Ellos, por su parte, habían luchado contra los moros para asegurar las fronteras y los trofeos obtenidos en las guerras fueron convertidos en generosas donaciones que contribuyeron al esplendor de las fábricas monásticas. Consecuentemente, estas quedaron muy alejadas de la pobreza y sobriedad que predicaba San Bernardo, al verse alteradas, casi de manera automática, por una sociedad medieval que transformó los rigurosos principios de la Orden abocándola a una crisis y, con ella, al fracaso espiritual. este paño de claustro, y dieron aqui los libros, y ornamentos que fueron de dicho arzobispo, como testamentarios suyos, que lo mando asi hacer. Pasaron de esta vida el año 1256 y el de 1259 (Viaje, op. cit., p. 812). Inscripción recogida en V. GARCÍA LOBO y Mª E. MARTíN LÓPEZ, "La publicidad en el Cister", op. cit., p. 60. Según A. García Flores ("Espacios funerarios", op. cit., p. 224) estas sepulturas quizás estuvieron monumentalizadas por lápidas; en la Relación de los sepulcros, fol. 69 y en los Epitafios del claustro se especifica que estas lápidas estaban enfrente del capítulo. 


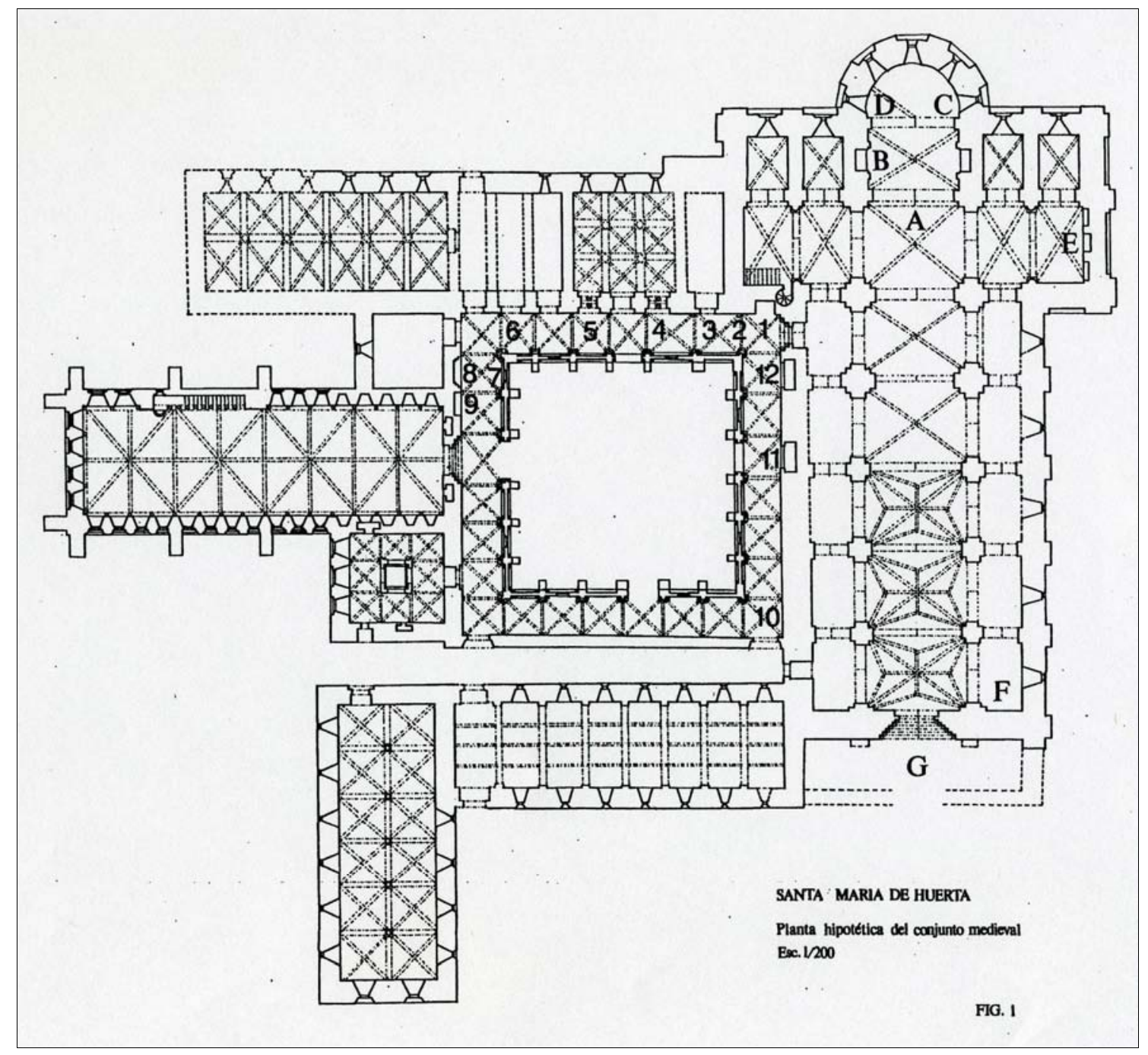

- Lám. 1. Plano del Monasterio de Huerta con la ubicación de los sepulcros (Corpus de Arquitectura Monástica Medieval, U.A.M). 


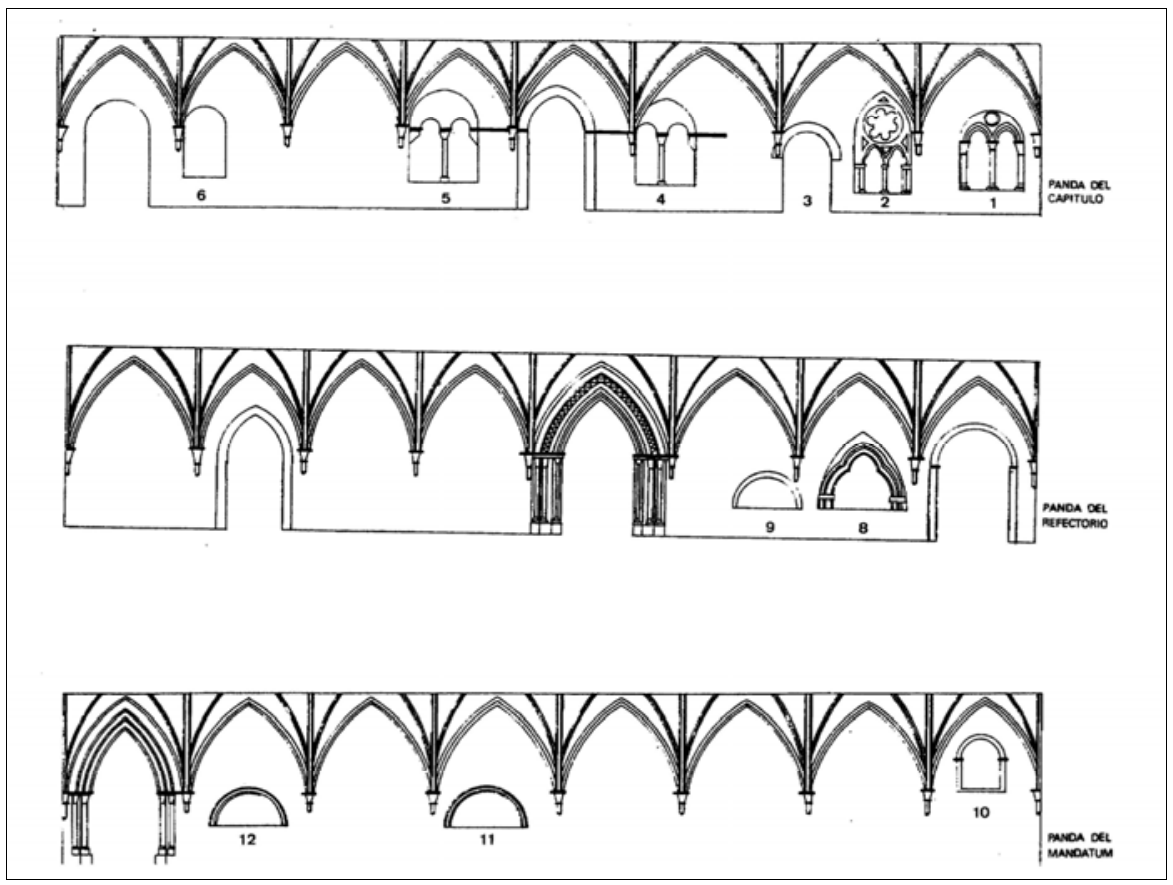

- Lám. 2. Sección de las pandas del claustro de Huerta con la ubicación de los sepulcros (Corpus de Arquitectura Monástica Medieval, U.A.M).

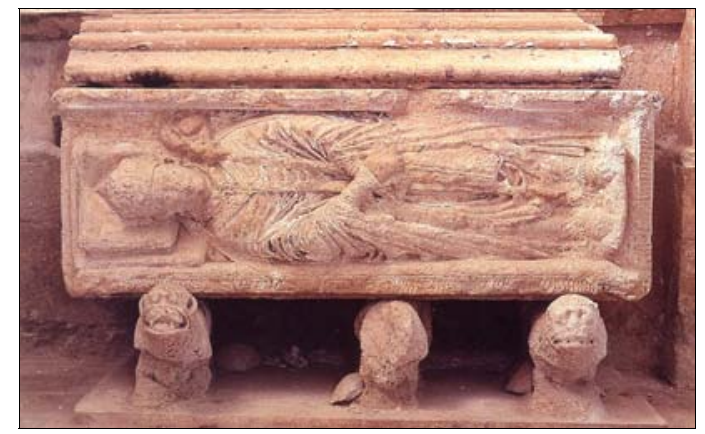

- Lám. 3. Santa María de Huerta. Iglesia, sepulcro de D. Rodrigo Jiménez de Rada.

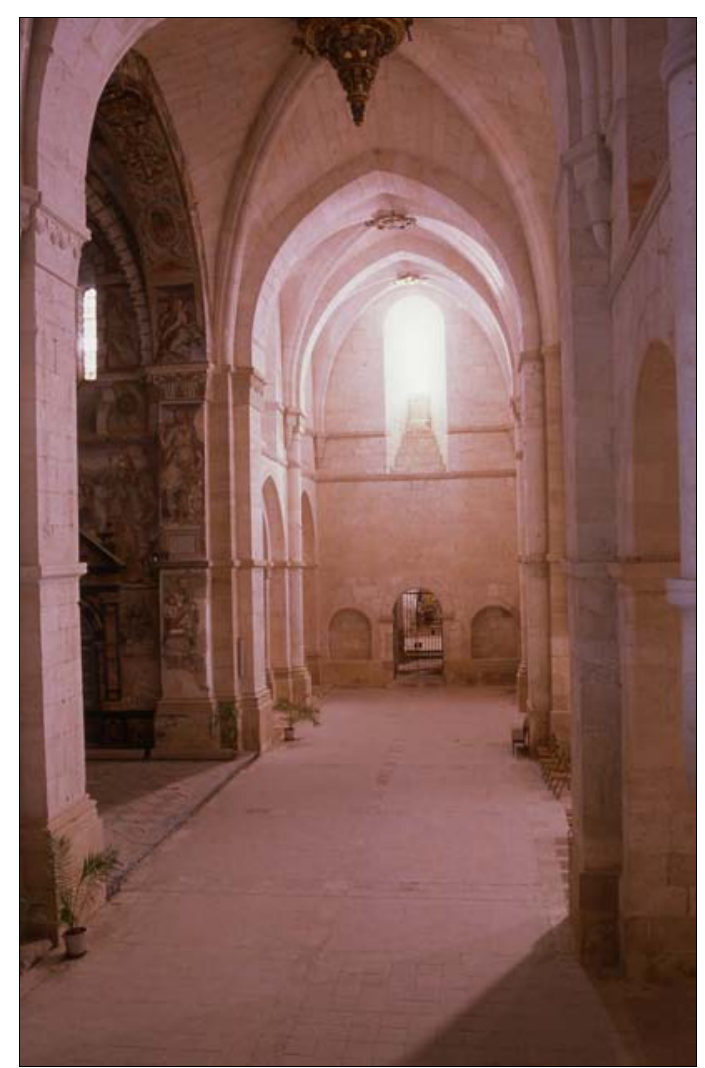

- Lám. 4. Santa María de Huerta. Iglesia, Brazo sur del transepto. 


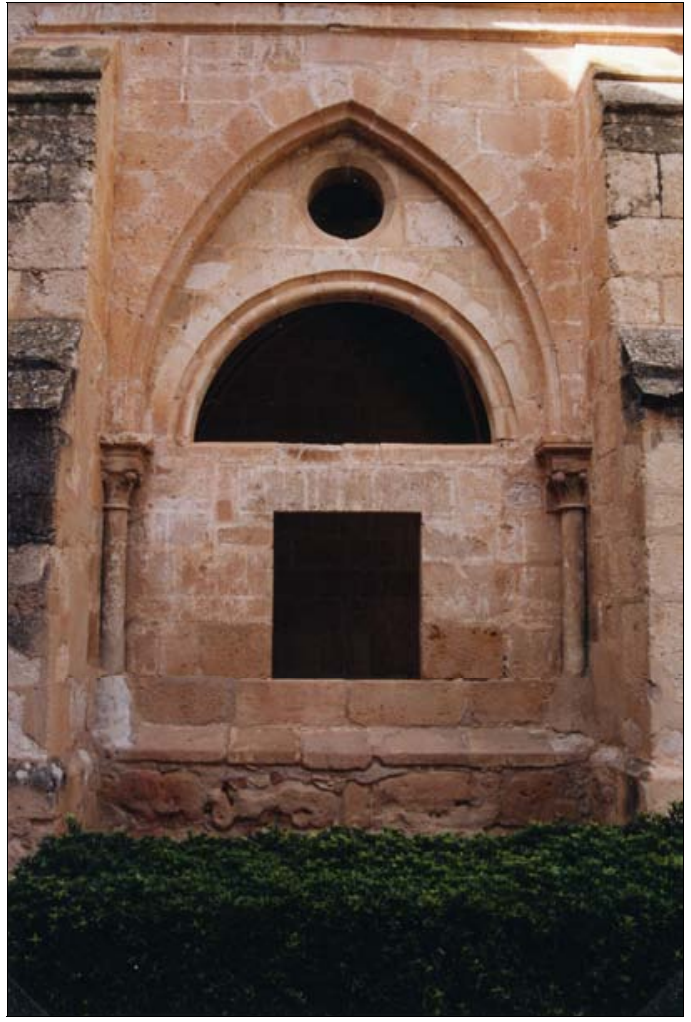

- Lám. 5. Santa María de Huerta. Intercolumnio cegado del claustro.

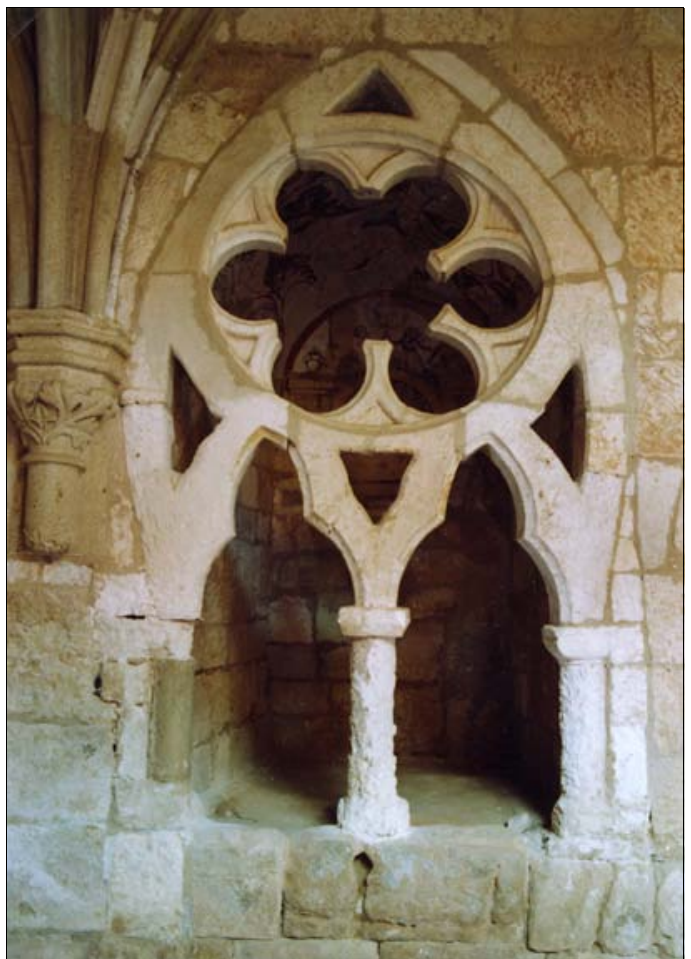

- Lám. 7. Santa María de Huerta. Panda del Capítulo, sepulcro no 2 .

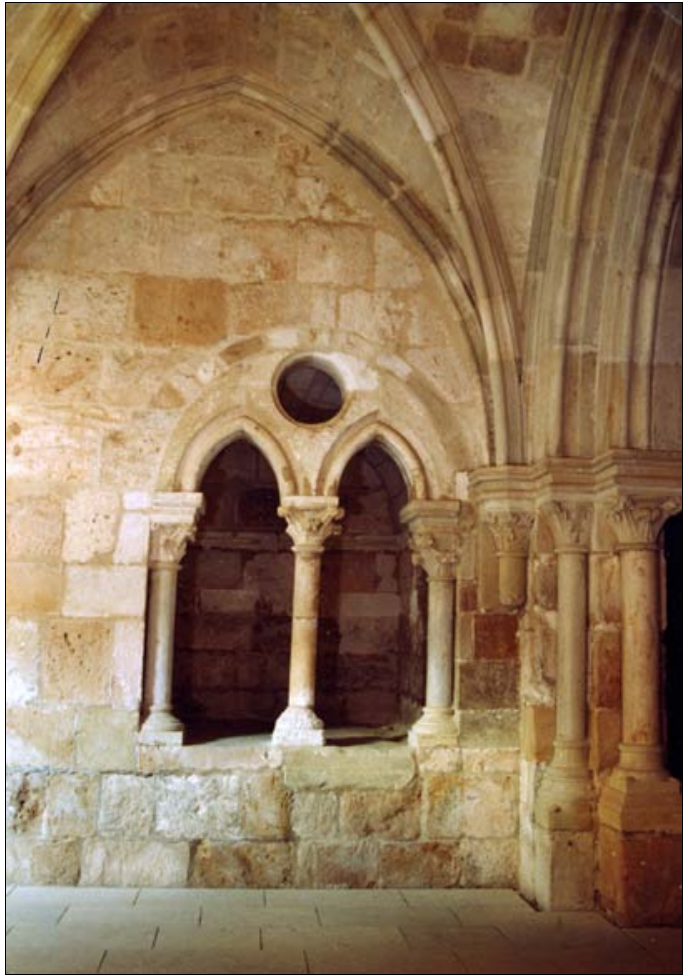

- Lám. 6. Santa María de Huerta. Panda del Capítulo, antiguo armariolum, sepulcro $\mathrm{n}^{\mathrm{o}} 1$.

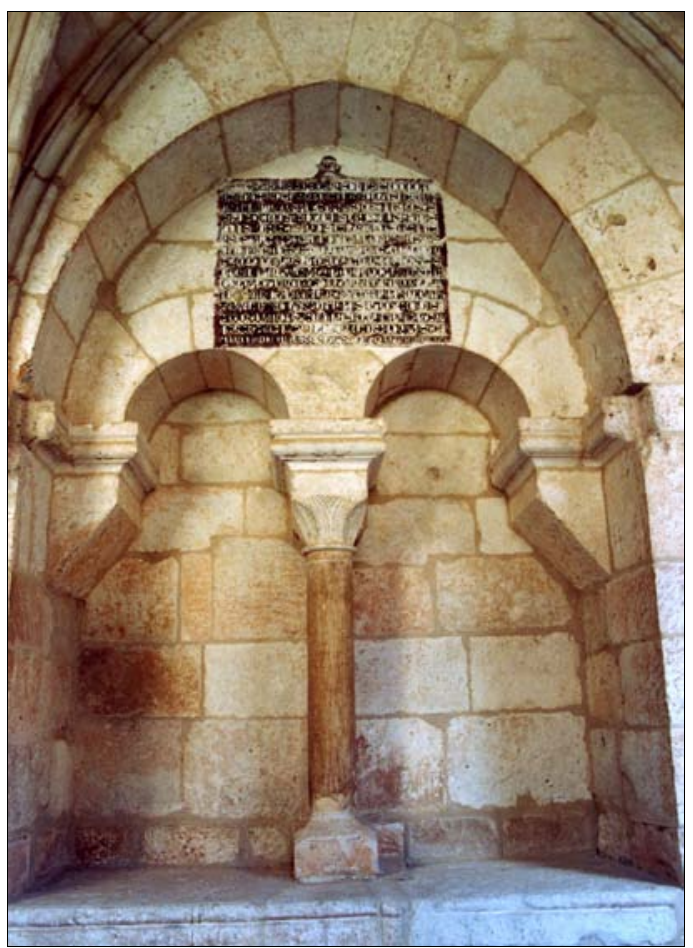

- Lám. 8. Santa María de Huerta. Panda del Capítulo, ventana Norte de la Sala Capitular, sepulcro $\mathrm{n}^{0} 5$. 


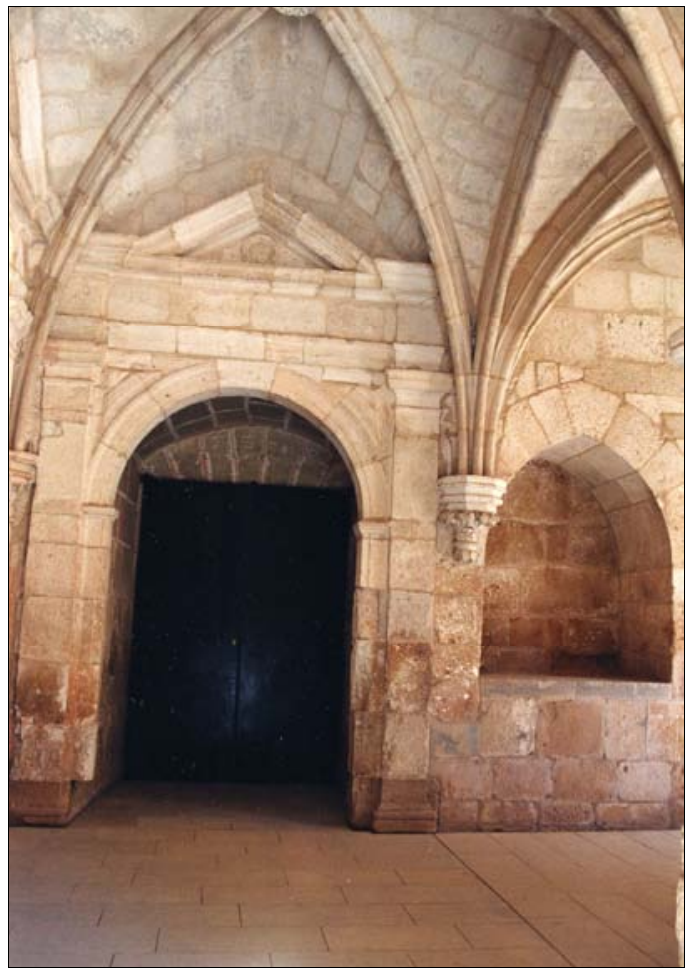

- Lám. 9. Santa María de Huerta. Panda del Capítulo, vano junto a la Sala de Profundis, sepulcro $\mathrm{n}^{\mathrm{o}} 6$.

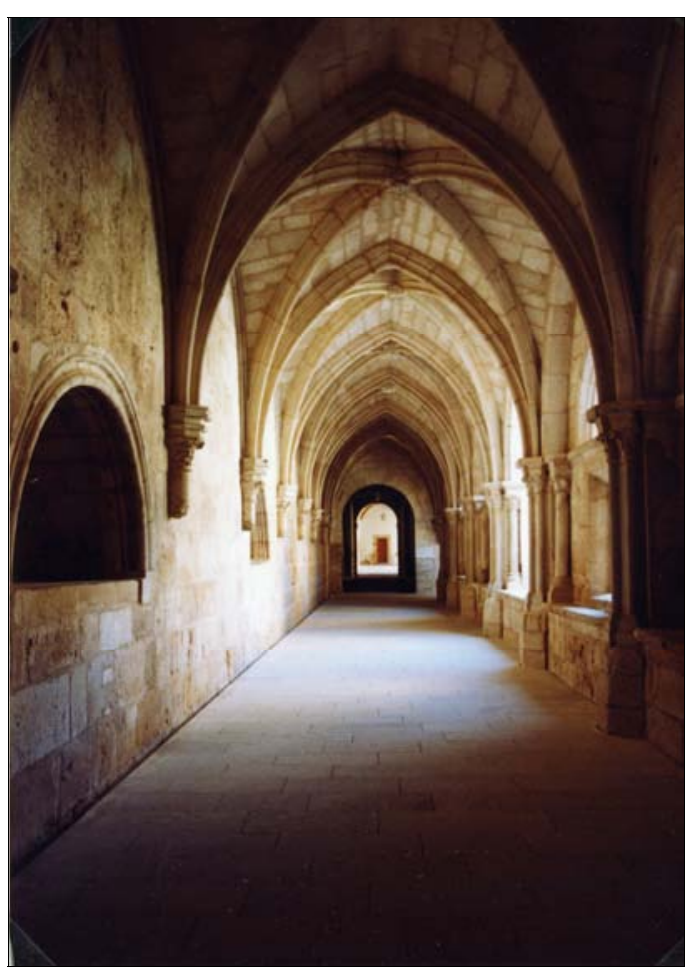

- Lám. 11. Santa María de Huerta. Panda del Mandatum, sepulcros no 12 y 11 .

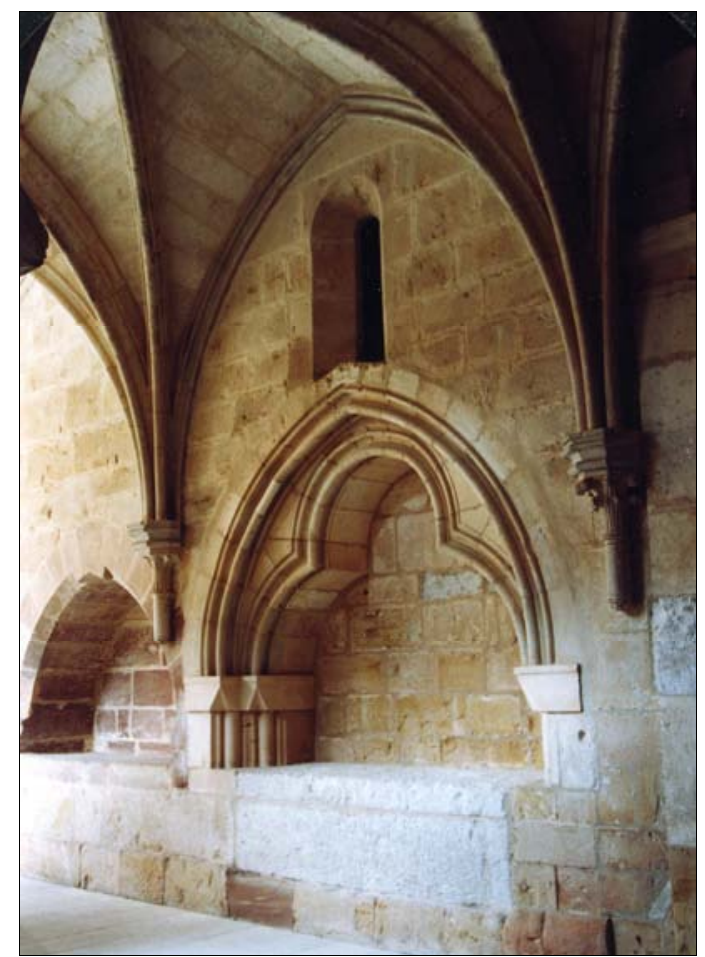

- Lám. 10. Santa María de Huerta. Panda del Refectorio, sepulcros no 8 y 9.

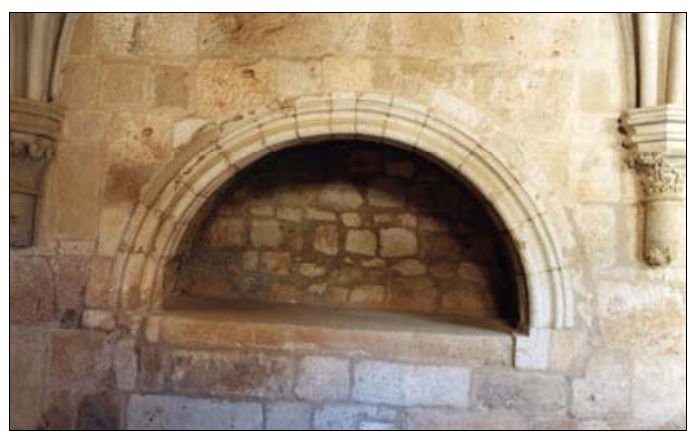

- Lám. 12. Santa María de Huerta. Panda del Mandatum, detalle sepulcro $\mathrm{n}^{\circ} 12$. 